\title{
DO BOARD INTERLOCKS INCREASE INNOVATION? EVIDENCE FROM A CORPORATE GOVERNANCE REFORM IN INDIA
}

\author{
Christian HELMERs ${ }^{a}$
}

\author{
Manasa PATNAM ${ }^{b}$ \\ a Santa Clara University \\ ${ }^{b}$ CREST (ENSAE) \\ ${ }^{c}$ University of Cambridge
}

P. Raghavendra RAU ${ }^{c}$

April 2017

Journal of Banking and Finance - forthcoming

\begin{abstract}
We examine the effect of board interlocks on patenting and R\&D spending for publicly traded companies in India. We exploit a corporate governance reform to address the endogeneity of board interlocks through exogenous changes mandated by the reform requiring a subset of firms to adjust their board structure. We rely on two difference-in-differences frameworks, comparing firms affected by the reform to unaffected firms as well as comparing within the set of firms that did not have to adjust their board structure those that still experienced an exogenous increase of their network size as a result of the reform to those that did not experience a change in their network size. We find that board interlocks have significant positive effects on both $R \& D$ and patenting. The evidence suggests that the impact on $R \& D$ is induced by information transmission through interlocks. The effect on patenting is driven by firms extending patent protection by patenting inventions abroad that they have already patented in India.
\end{abstract}

KEYWORDS: Patents, peer effects, director networks, innovation, India, natural experiments

JEL Classification: G3, O16, O34, O31 


\section{INTRODUCTION}

The academic literature has examined both the intentional and unintentional transmission of knowledge across companies (Jaffe et al., 1993; Audretsch and Feldman, 1996). However, there is relatively little research on the specific channels through which information is transmitted between companies. The extant literature suggests that knowledge is shared among firms through networks created by different types of links such as strategic alliances (Schilling and Phelps, 2007) or formal and informal research collaboration (Hagedoorn et al., 2000).

In this paper, we focus on how information transmission occurs through the presence of interlocking boards of directors across firms using a large sample of publicly listed Indian firms between 2000-2007. Specifically, we examine whether independent directors transfer information across firms when they serve on interlocking boards and whether these transfers affect companies' innovative (measured by $R \& D$ expenditure) and patenting activities.

Investigating the role interlocks play in innovation is important since one of the key strategic decisions for which the board of directors is responsible is the firm's level of investment in innovation, including its approach to knowledge and intellectual property (IP) management. A priori, it may appear unlikely that the board of directors is directly involved in determining specific R\&D activities since they typically do not have sufficient technical expertise. However, there is evidence that boards do play a managerial role in addition to their supervisory role (Schwartz-Ziv and Weisbach, 2013). Given the number of items on a typical board agenda, it is plausible that board members contribute to raising the importance and attention allocated to specific R\&D directions set by the firm. Specifically, while a board member is unlikely to suggest a brand new direction for innovation or R\&D, the member may suggest that the firm pay greater attention to some innovative activities over others or may influence strategic decisions that affect a firm's innovative as well as patenting 
decisions. ${ }^{1}$ The larger the network size of the board, the more the directors are likely to be exposed to external information and hence, the more likely they are to suggest changes in emphasis on the specific innovative activities of the firm.

Moreover, the need for direct board oversight, specifically of matters relating to IP, has increased enormously over the past decade and a half as the stakes involved in IP have often become critical. IP, particularly in the form of patents, assumes an important role both as a highly valuable intangible asset and as a strategic tool or threat in high-stake litigation. ${ }^{2}$ IP related concerns often also play a role in M\&A decisions, where directors have been shown to play significant roles, when companies choose their targets at least in part based on their targets' patent portfolios. The provision of information by a company's board is vital to undertaking such IP related decisions because managers often face a fair amount of uncertainty with regard to the eventual viability/success of specific actions and investments.

In our paper, we examine changes in board networks following an exogenous change, the Clause 49 reform, in corporate governance requirements in India. The Clause 49 reform required firms to change the composition of their board of directors - specifically, at least 50 percent of the board had to consist of non-executive directors. This regulation caused an exogenous change in network size (the number of board interlocks) for at least some Indian firms and we rely on it to isolate the impact of interlocks on companies' R\&D expenditure as well as patenting behavior. We create a novel dataset that combines detailed balance sheet information, board composition, data on R\&D expenditures, and information on companies' patenting activities. Since patent data for India, in particular for the early 2000s, is not readily available, we compile a database that contains the universe of patent filings with the Indian patent office and match these patents to companies. In order to capture Indian companies' international patenting activity, we also match our sample of Indian companies

\footnotetext{
${ }^{1}$ Based on our conversations with board members. In addition, all board members usually weigh in on the business model, which includes the level of R\&D as a percentage of overall revenues and try and influence the productivity of R\&D with ideas on outsourcing, offshoring, or acquisitions.

${ }^{2}$ Sterne and Chaplick (2005) argue that under U.S. corporate governance law, lack of direct oversight of IP matters by a company's directors exposes the board to legal liability for failure of oversight.
} 
to U.S. and European patents.

India is an appropriate environment to study the effect of interlocks on innovation and patenting for two major reasons. First, besides being one of the largest emerging market economies, it follows a common law legal regime, similar to the U.S. and the United Kingdom. Black and Khanna (2007) document how India substantially reformed its corporate governance practices beginning in the late 1990s. In particular, the Clause 49 reform is similar to the requirements of the Sarbanes-Oxley Act in the U.S., ${ }^{3}$ and Black and Khanna (2007) among others, argue that corporate governance requirements in India are now largely comparable to those in developed common law countries. Hence, results from India are relatively easily generalizable to the rest of the world. Second, it is easier to detect the effect of board interlocks on innovation and patenting in India. There have been large increases in $\mathrm{R} \& \mathrm{D}$ spending over the past decade in India. ${ }^{4}$ There has also been a significant increase in the number of patents granted to Indian firms over the past decade. ${ }^{5}$ Hence, both the low base and the significant growth in innovation and patent filings make it easier to detect the influence of board size on innovation in India relative to other countries.

In our empirical analysis, we use two different methodologies to exploit how the number of interlocks changes as a result of the reforms. First, we exploit both the compliance requirement and the timing of the reform to instrument for the number of interlocks. We compare firms that fell short of the board restructuring requirement and those that did not at the time of the reform to isolate variation in the size of boardroom networks. Our instrumental variable strategy implicitly controls for required firm compliance as well the cumulative effect of the reform, by employing firm and time fixed effects together with a

\footnotetext{
${ }^{3}$ Clause 49 requires, among other things, audit committees, a minimum number of independent directors, and $\mathrm{CEO} / \mathrm{CFO}$ certification of financial statements and internal controls.

${ }^{4}$ According to the Indian Department of Science and Technology, R\&D spending in the manufacturing industry has increased on average by nearly 20 percent annually between 2005 and 2010 .

${ }^{5}$ Domestic patent filings increased at an average annual rate of 16 percent between 2000 and 2011 according to WIPO (2013). Note that there has also been an important change in the Indian patent system in 2005 due to the Trade-Related Aspects of Intellectual Property Rights (TRIPS) Agreement (we describe the relevant changes in online appendix D and explore potential implications for our analysis in online appendix E).
} 
rich set of board controls. Second, we rely on a regression discontinuity design (RDD), exploiting the threshold related to board composition that determined whether firms were required to adjust. In this strategy, we explicitly control for the time-varying nature of the board independence requirement, hence allowing the board structure to directly affect the outcome. Therefore, differences across subsets of firms are absorbed non-parametrically by an analysis of the close neighbourhood around the threshold.

We find that the exogenous increase in the number of interlocks has a large, positive effect on the number of patents filed by companies and their R\&D expenditure. The instrumental variable approach suggests that network size only affects current R\&D expenditure and a firm's patent filings abroad. In other words, companies react to an increase in network size by spending more on short-term R\&D and by also seeking patent protection abroad.

One concern with our identification strategy is that the reform could generate differential effects, based on a firm's eligibility, independent of its effect on interlocks. For instance, it is plausible that, instead of being driven by network size effects, the innovation strategy of below threshold firms benefited from better corporate governance as a result of adding independent (external) directors because of the reform. If this were the case, the reform would have a direct effect on the outcome and would invalidate our instrument. To assess the sensitivity of our results to this concern, we use a third identification strategy.

Specifically, we focus only on those companies that did not fall short of the board restructuring requirement and compare those that still experienced an increase in network size (because some of their directors were hired by firms that had to comply with the reform) and those that did not. In this way, we are able to rule out the the independent director' effect as none of the firms in our sample for this strategy hired or fired any directors during this period. Our identification is therefore immune to any selection concerns. This difference-in-differences approach takes advantage of the fact that the new directors hired by the below-threshold firms to comply with the mandated board structure requirements typically came from above-threshold firms. The above-threshold firms were already 
compliant with the mandate. Hence, controlling for the number of new hires at the abovethreshold firms, the increase in network size for these firms comes only from their directors being hired by below-threshold firms. This more restrictive approach produces the same findings as those obtained from the instrumental variable and RDD approaches that rely on the entire set of firms.

Finally, we explore the mechanisms by which an increase in network size could potentially affect a firm's R\&D expenditure and patenting behaviour. In particular, we examine if the effect of network size on firm R\&D and patenting is explained by peer effects, that is, by changes in average R\&D investment and patenting by other firms in a firm's network formed by board interlocks. Our results indicate that this is indeed the mechanism; a one unit increase in average network R\&D increases the target firm's own R\&D by 0.193 units. We further show that this effect is larger the closer firms are in their technology spaces.

We also show that the difference in the effect on domestic vs. international patenting is explained by Indian companies filing for patents abroad on inventions that are already patented domestically. ${ }^{6}$ Such a strategic effect is consistent with the short time lag between the changes in board interlocks and patenting in our analysis. Our results thus indicate an economically significant change in firms' IP strategy as a result of new information transmitted by interlocked directors.

This paper contributes to two different streams of literature. First, it contributes to the literature on how innovation occurs in firms. Prior literature has argued that innovation that is generated through inter-firm interactions usually occurs through explicit contracting forms such as strategic partnerships, business groups, or corporate networks. For example, firms that share a formal alliance through a strategic partnership are more likely to share technological knowledge, thereby increasing their propensity to patent (Gomes-Casseres et al., 2006). Similarly, formal business group affiliations have also been shown to be strong

\footnotetext{
${ }^{6}$ Patents are national rights. If an Indian company wants to obtain patent protection in, for example, India and the U.S., the firm has to file separate patent applications in each country.
} 
predictors for firm innovative activity (Chang et al., 2006; Belenzon and Berkovitz, 2010). There is, however, little evidence in the literature on how boards affect innovation and information transfers between firms. Among the exceptions, Oh and Barker (2015) find that when CEOs serve as independent board members on other firms, they imitate the R\&D intensity of the interlocked firms in their own firm's R\&D decisions. Balsmeier et al. (2014a) show that outside directors increase patenting activities at the firms they advise and monitor. This effect increases with the technological proximity between the appointing firm and the outsider's home firm. Mallapragada et al. (2015) suggest that new product introductions by companies in the food and beverage sector are positively correlated with a measure of board interlocks between firms. Finally, Balsmeier et al. (2014b) argue that boards monitor management and more independent boards are less likely to approve riskier and explorative search strategies. They find a negative relationship between board independence and firm propensity to explore new-to-the firm technologies and to hire younger and new-to-the firm inventors. In contrast to the other papers, their model focuses solely on the monitoring role of boards, ignoring the advisory role. Our analysis contributes to this literature by providing evidence that the sharing of board members across companies is another factor that influences companies' innovative and patenting activities.

Second, it contributes to a growing body of literature that examines the advisory role of boards (Haunschild and Beckman, 1998; Kor and Sundaramurthy, 2008). As mentioned above, the advisory role of directors has been documented in investment policy, during acquisitions, in customer or supplier relationships, and in managing foreign operations. Our paper adds to this literature by providing evidence on how boards aid in information transfer and innovative activities among firms.

The remainder of the paper is organized as follows. Section 2 discusses the Clause 49 corporate governance reform. We describe the data in Section 3. Section 4 discusses the identification strategy and the empirical framework. Section 5 discusses the results and Section 6 concludes. 


\section{Corporate Governance Reforms - Clause 49A}

Black and Khanna (2007) provide an overview of the history of corporate governance reform in India and the background for the Clause 49 reform. Briefly, in 2000, on the recommendation of the Kumarmangalam Birla Committee (KMBC) on corporate governance, the Security and Exchange Board of India (SEBI) made several amendments to Clause 49 of the Listing Agreement of the Stock Exchanges. Clause 49 replaced an earlier voluntary corporate governance code and contained both (non-binding) recommendations and (binding) requirements for listed firms, following closely corporate governance models in the U.S. and the UK. The reforms were mainly motivated by a series of corporate scandals in the 1990s and a general perception that oversight exerted by boards was largely ineffective (Dharmapala and Khanna, 2013). Another important motivation behind the corporate governance reform was the general opening up of the Indian economy during that time period and improved access to institutional investors both domestically and abroad (Chakrabarti et al., 2008). The main goal of the reform was, therefore, to strengthen oversight by improving board independence and tightening disclosure requirements.

For the purposes of our analysis, the most relevant aspect of the reform is a required change in the composition of the board of directors: at least 50 percent of the board had to consist of non-executive directors. It also required changes with regard to the proportion of independent directors on a board. ${ }^{7}$ The exact proportion depended on whether the chairman was an executive or non-executive. In case of a non-executive chairman, at least one-third of the board was required to be composed of independent directors. In case of an executive chairman, at least half of the board was required to be composed of inde-

\footnotetext{
${ }^{7}$ An 'independent director' is defined as one who "[...] apart from receiving director's remuneration, does not have any material pecuniary relationships or transactions with the company, its promoters, its senior management, its holding company, its subsidiaries and associated companies; is not related to promoters or management at the board level or at one level below the board; has not been an executive of the company in the immediately preceding three financial years; is not a partner or an executive of the statutory audit firm or the internal audit firm that is associated with the company, and has not been a partner or an executive of any such firm for the last three years" (SEBI, Clause 49A, p. 1).
} 
pendent directors (SEBI, Clause 49A). The reforms also laid down a code of conduct for directors and senior managers, board procedures, compensation to non-executive directors, audit committee requirements, term limits, disclosure requirements, and whistle blower policy regulations. These changes were focused on improving the auditing of companies through the board. They are unlikely to confound the effect of the changed board structure requirements which we rely on for our analysis.

The creation and membership of the KMBC was announced on May 7, 1999. The committee's tentative recommendations were issued on September 30, 1999, less than five months later - an extremely short period for India. The committee issued its final report on January 26, 2000; its proposals were adopted by SEBI almost immediately on February 21, 2000, and became effective for large firms one year later, on March 31, 2001. This leaves an extraordinarily short time window for companies to anticipate any of the eventual changes in corporate governance that form the basis of our identification strategy.

Firms were required to submit quarterly compliance reports to SEBI and those failing to meet the requirements of Clause 49 were subject to fines and potential delisting. This led to very high compliance rates; Sarkar (2009) indicates that only around 4 percent of listed companies did not comply with the required 50 percent minimum share of non-executives. For more details, see online appendix A.

SEBI required schedule-wise implementation of the mandated share of non-executives. Group A firms on the BSE were expected to comply by March 31, 2001 (i.e. from fiscal year 2001 onward). These are generally the largest corporations in the Indian economy. Group $B$ firms or firms that had a paid up share capital of at least INR 10 crores (approximately US\$ 2.22 million (as of 2001) or net worth of more than INR 25 crores (US\$ 5.55 million) at any time in the company's history, were expected to comply by March 31, 2002 (i.e. from fiscal year 2002 onward). Finally, other firms with paid up share capital of at least INR 3 crores (US\$ 0.66 million) were expected to comply by March 31, 2003 (i.e. from fiscal year 2003 onward). Listed companies with a paid up share capital of below INR 3 crore or net 
worth of INR 25 crores or less at any time in the history of the entity were not required to comply with these measures.

In our analysis, we control for any potential direct effect of the reform by explicitly including dummies for each reform year. Overall, we exploit only the differential impact of the reform applicable to the subset of firms who were specifically required to comply with the board restructuring clause. These were firms which did not meet the board structure requirement before the reform period, i.e., their board structure had less than the required number of independent directors and therefore had to restructure to meet the board structure requirement.

\section{DATA}

\subsection{Firm-LEVEL DATA}

We use data for all publicly listed companies in India - including the Bombay Stock Exchange (BSE) and the National Stock Exchange (NSE) - during the period 2000-2007. We stop our analysis at the end of fiscal year 2007 to avoid the effect of the global financial crisis and a revision of Clause 49 in 2008 on firm behavior. The data comes from PROWESS, which is a firm-level database provided by the Centre for Monitoring Indian Economy (CMIE). For each publicly traded Indian firm, we obtain detailed information on accounting balance sheets, financial statements, industry information, group affiliation for each firm, corporate ownership data and share prices. The database also includes information on R\&D. R\&D is measured as the total outlay of the company on research and development during the year on its current and capital account. R\&D expenditure is classified as capital R\&D when the firm invests in long-term fixed assets related to $R \& D$, that can be amortized over a period longer than one fiscal period. In contrast, R\&D expenditure on the current account refers to 
short-term spending that is fully expensed in the fiscal period in which it is incurred. ${ }^{8} \mathrm{We}$ obtain an unbalanced panel as the annual reports for some companies are missing in some time periods.

As in other papers (Khanna and Palepu, 2000; Bertrand et al., 2002), we rely on CMIE to classify our sample firms into business and non-business group firms, and to identify firms' specific group affiliation. This information allows us to disentangle interlock effects from business-group effects. For identifying industry affiliation, we use information on the principal line of activity of the firm and use the National Industry Classification (NIC) code accorded to them. The Prowess data also provides detailed information on the directors serving on the board of each firm, along with information on the number of board meetings attended, salary, directors' fee etc. The listing of these directors is unique within each time period and we undertake an exhaustive matching exercise to ensure uniqueness across time periods. ${ }^{9}$

We use a parsimonious specification in our analysis to control for other exogenous firm characteristics. Specifically, we include total book value of assets (in logs) to control for firm size. We also include total exports divided by sales of the company (in logs) to capture the effect of trade on innovation and patenting (Baldwin and Gu, 2004; Melitz and Trefler, 2012). We also include the company's board size to account for scale effects and control directly for the share of non-executive directors on the board. We include the average number of directorships held by a firm's directors at other companies among the covariates to account for "busy" directors. Further, we include Tobin's Q (computed as the M/B ratio) to proxy for firm growth opportunities. We construct an industry-level patenting propensity variable (number of patents divided by $R \& D$ investment) that captures time-varying

\footnotetext{
${ }^{8}$ This is similar to the U.S., where Internal Revenue Service (IRS) rules define R\&D expenditures to generally include all expenditures incident to the development or improvement of a product. R\&D expenditures include the expenditures of obtaining a patent, such as attorney's fees expended in making and perfecting a patent application. These can be expensed in the first year of incurring the expenditures or capitalized over the long term.

${ }^{9}$ We only observe the list of board members at the beginning of each fiscal year, which means changes in board structure are measured on an annual (fiscal year) basis.
} 
industry-specific patent-related effects (Hall and Ziedonis, 2001). Finally, though firm fixed effects are likely to absorb business group effects, we also capture potentially time-varying resource sharing effects within business groups through a separate variable that measures patenting propensities within business groups. All control variables are lagged by one year.

Table 1 shows the corresponding descriptive statistics for the firms included in our regression analysis. In addition, Table 2 provides a breakdown of average R\&D expenditure, patent counts, number of interlocks, and company characteristics across the different eligible company categories before and after the reforms became effective. The table also distinguishes between companies that were below and those that were above the required board composition threshold. The table shows that the network size changed significantly across all company categories regardless of whether a company was below or above the threshold - this is discussed in detail in Section 4.1. To alleviate concerns that differences across groups are driven by industry specific characteristics due to the skewed distribution of R\&D investment and patent filings across industries, Table B1 in the appendix shows the same statistics as in Table 2 after demeaning the variables using industry averages. Our results remain qualitatively similar under this alternate measure.

\subsection{Patent Data}

For international patent filings with the U.S. Patent and Trademark Office (USPTO) and the European Patent Office (EPO), we rely on EPO's PATSTAT database (version April 2010). ${ }^{10}$ While the USPTO and EPO data are relatively complete, there is serious under-reporting in PATSTAT of Indian domestic patent filings with the Indian Patent Office (CGPDT). We therefore rely instead on three other databases. The electronic patent search facility available on CGPDT's website iPairs provides information on published patents only from 2005

\footnotetext{
${ }^{10}$ This includes patents filed with the World Intellectual Property Organization (WIPO) through the PCT route.
} 
onwards. ${ }^{11}$ For patent filings before 2005, we rely on the EKASWA database assembled by the Patent Facilitating Centre (PFC) of the Indian Department of Science and Technology. EKASWA contains all domestic patents published between January 1995 and early $2005 .{ }^{12}$ Finally, we complement the official data sources using the online portal BigPatents India. ${ }^{13}$ Our analysis focuses on the application date of a patent. ${ }^{14}$ However, patent data are only visible after a patent has been published. Given a usual 18-month delay between application and publication date at USPTO, EPO and CGPDT, this implies that we have patent data until March 2009. ${ }^{15}$ As an alternative to simple patent counts, we also use the number of citations received by patents. These forward citations are retrieved from a 2015 version of PATSTAT to limit the effect of citation lags. For robustness, we also create citation counts where we limit the gap between the publication date of the cited patent and the priority date of the citing patent to 3,5 , and 10 years. Since the citation data have to be extracted from PATSTAT, they are only available for filings with the USPTO and the EPO; so far no citation data for Indian patents are available. To construct technological similarity measures between firms, we also extract IPC codes. IPC codes for U.S. and European patents are extracted from PATSTAT, while IPC codes for Indian filings are retrieved directly from the Indian patent office's website.

Due to the absence of a unique identifier shared by the firm-level and patent data, the main problem in constructing our dataset consists in matching patents to firms. To match assignee names to company names, we rely on a combination of an automated matching

\footnotetext{
${ }^{11}$ The search facility also provides information on granted patents before 2005. This, however, misses any patent that was not granted. Given our research objective, we are interested in any patent filing, independent of whether it was eventually granted.

${ }^{12}$ The data in EKASWA come from the Patent Office Gazette, which was published only in print format. The Gazette was replaced in 2005 by the Patent Journal, which is published both in print and electronic formats.

${ }^{13} \mathrm{http}: / /$ india.bigpatents.org

${ }^{14}$ Note that our accounting data are reported by fiscal year, that is, from 1st April in a given calendar year to 31st March of the subsequent calendar year. Therefore, we also allocate patents accordingly into fiscal year intervals based on their precise application date.

${ }^{15}$ Though PATSTAT reports patent data from 1990 and EKWASA from 1995, firm-level information is only available from 1999. Since we arrange the data by fiscal year, the time series used in our analysis extends into 2008 (until the 31st March) despite the fact that we only use firm-level data up to 2007.
} 
algorithm and extensive manual checking of the (un)matched data. We also cross-check matched domestic Indian, USPTO, and EPO patents using 'equivalents', that is, we verify whether, for example, a given matched USPTO patent has an EPO equivalent for the same innovation and whether this EPO equivalent had been matched (and vice versa). ${ }^{16}$ Section $\mathrm{C}$ of the online appendix explains the matching algorithm and outcome in more detail.

\section{EMpirical Strategy}

There are two major issues that need to be addressed when studying the effect of interlocks on information transfer. One is the question of reverse causality - that firms hire directors because they need help in taking a particular decision, and not because the directors influence the firm to take the decision. For example, Harford and Schonlau (2013) and Field and Mkrtchyan (2014) document that firms that hire directors with acquisition experience are more likely to make acquisitions in the near future, and suggest that firms choose to hire such directors for their expertise. The prior literature typically addresses reverse causality by examining changes in firm behavior following changes in directors at the firms, usually with a lag long enough to reduce the likelihood of reverse causality. ${ }^{17}$

The second issue, which is arguably more difficult to address, is the question of omitted variables. Boards and firms match assortatively on a number of characteristics such as size. Do et al. (2014) document, for example, that better qualified directors join larger firms. The issue here is that the presence of a director on two separate boards merely reflects an underlying similarity between the two firms and this similarity causes the two firms to behave similarly. In our context, similar innovative activity between firms with interlocked boards could in part reflect a tendency by high inventive capacity firms to simultaneously work on similar recent technological developments, rather than being influenced to do so by

\footnotetext{
${ }^{16}$ For EPO and USPTO patents, our definition of equivalents follows Martinez (2010). Since we do not have priority information for the domestic Indian patents, we retrieve Indian equivalents of matched EPO and USPTO from EPO's Espacenet.

${ }^{17}$ See for example Stuart and Yim (2010) or Fracassi and Tate (2012).
} 
a shared board member who transfers information across them. Alternatively, a firm could employ a board member from a technologically superior firm precisely to take advantage of the other firm's knowledge base, rather than the board member providing that information after arrival and influencing the firm to alter its innovative activity. These types of strategic behavior, associated with the formation of interlocks, but unobservable to the researcher, confound estimates of board interlock effects. For example, in Balsmeier et al. (2014a), only outside directors from innovative firms increase patenting activities at the firms they advise. Outside directors from non-innovative firms are negatively associated with the appointing firm's innovativeness. Similarly, in Oh and Barker (2015), the performance of the interlocked firm could be driving both the longer tenure of the CEO-director and the R\&D intensity of the firm.

Our variable of primary interest is the network size of a firm, which is the sum of a firm's corporate network links created through interlocking boards of directors: ${ }^{18} N_{i t}=$ $\sum_{j=1}^{J} I\left(n_{i j t} \geq 1\right)$ where $N_{i t}$ is the network size of firm $i$ in time period $t$ and $I\left(n_{i j t} \geq 1\right)$ is an indicator function which is equal to one if firms $i$ and $j$ share at least one interlocked director in period $t .{ }^{19}$ An interlock occurs when a director of the board of one firm also sits on the board of another company. A firm can have one or more directors who sit on the boards of other firms. While firms can also be connected through social ties between directors based on shared educational background of executives or past employment of employees, our data does not allow us to identify such potential connections. Therefore, in our paper, we focus specifically on direct inter-company relationships through interlocked boards. ${ }^{20}$

\footnotetext{
${ }^{18}$ In our analysis, we distinguish these board interlock connections from links that result from business group affiliations.

${ }^{19}$ This means that we only count direct network links.

${ }^{20}$ Throughout the paper, we measure interlocks between all listed companies in India. However, the directors of each listed company also serve on boards of non-listed companies. Since these non-listed companies are not part of the sample, our measure of network size omits linkages between listed and non-listed companies, thereby inducing potential measurement error. However, the extent of this measurement error is likely to be negligible since the bulk of non-listed companies belong to industries that neither conduct much formal R\&D nor rely on patents to protect their inventions. Including these companies is likely only to serve to inflate our network size measure, without adding any value to the informational content contained in the networks.
} 
Our objective is to examine whether firms with larger networks file more patents and spend more on R\&D. ${ }^{21}$ The equation of interest measuring the effect of network size on patent counts or $R \& D$ expenditure therefore is:

$$
y_{i t}=\alpha+\beta N_{i t}+\gamma x_{i t-1}+\mu_{i}+\gamma_{t}+u_{i t}
$$

where $y_{i t}$ is one of three separate firm-specific outcome measures - R\&D expenditure, patent counts (domestic as well as international patents), and the ratio of patent counts to $\mathrm{R} \& \mathrm{D}$ (as a measure of patenting propensity). ${ }^{22} N_{i t}$ is the network size as defined above, $\mu_{i}$ represents firm fixed effects and $\gamma_{t}$ includes year dummies.

As noted at the beginning of this section, there are several empirical issues with this analysis. First, the Ordinary Least Squares (OLS) estimate of network size in Equation (1) will be inconsistent if network size is endogenous. Second, better performing and more innovative firms may strategically place themselves in a network, leading to reverse causality issues. Third, more centrally located firms may also be more likely to perceive the need to use patents strategically. Finally, unobserved factors that affect both network size and output measures could cause an omitted variable bias.

To address the endogeneity problem, we use the exogenous variation brought about by the corporate governance reform described in Section 2. As mentioned previously, the reforms prescribed minimum percentages of non-executive directors for all publicly listed firms. Firms that did not comply with the requirement faced significant penalties and possible de-listing. To create an instrument that is uncorrelated with the second stage error but is able to predict network size, we make use of the board structure of firms before the

\footnotetext{
${ }^{21}$ We use network size rather than structure as our primary determinant of a firm's innovative behavior. This is justified by a high correlation of network size and network structure in our data. For example, in our sample, the correlation coefficient of a firm's betweenness centrality and network size is 0.84 , where the betweenness centrality is a measure of how important a node is in terms of connecting other nodes.

${ }^{22}$ Patent propensity measures the number of patents filed by a company relative to its total R\&D expenditure (Hall and Ziedonis, 2001). This allows us to ask whether the number of patents per Rupee spent on R\&D varies as a function of interlocks.
} 
reform period. We exploit the fact that the corporate governance reform de facto required only some firms to restructure their board. That means we have two types of firms (also illustrated in Figure 1):

Below-threshold firms with boards where the required proportion of non-executives was below that required by the reform. These firms needed to comply with the reform by adjusting their board composition to fulfill the proposed criteria.

Above-threshold firms with boards where the required proportion of non-executives was above that required by the reform. These firms did not need to adjust their board composition.

Our empirical strategy isolates the differential effect of the reform on the network size of above- and below-threshold firms. Our instrument, therefore, combines the interactive effect of the reform period and whether firms fell below the board composition requirement. An issue of concern is that the timing of compliance was defined by firm size. As a result, the average size of firms that have to comply earlier is larger than that of firms that had to comply later. We account for this in two ways: we use firm fixed effects to absorb the initial size differences in firms and the change in total assets for any given firm over time to address later changes in size differences.

\subsection{Reform SHOCK AND NetWork CHOICE}

We first document how networks changed as a result of the reform, by exploring the network dynamics for the above- and below-threshold firms around the reform period. In Panel A of Table 3, we present summary statistics on changes in network dynamics for the above and below threshold firms around the reform period. The first two columns split the firmyear sample by pre-reform and post-reform and above- and below-threshold firms. We find that the reform increased the total network size of both types of firms but the increase was more pronounced for the firms above the threshold. This post-reform difference, 2.174, 
is statistically significant at the 1 percent level. Firms for which the reform was binding increased their number of interlocks less than firms that the reform left unaffected.

To explore this further, we divide the network size gain for each firm in three parts: the network gained on behalf of newly appointed directors (hires), the network lost on behalf of exiting directors (fires) and finally the network gained on behalf of sitting directors (remaining). We then compute the average post- and pre-reform differential between network size gains for each of these subcomponents. We find that the average gain in network size to firms from their hires of new directors net of their fires of 'old' directors are similar across the two types of firms (above and below threshold) and not statistically significant. However, we find a positive and significant difference in the network gain from existing/sitting directors between above and below threshold firms. To summarize, the network size gain to firms from existing directors' interlocks is higher for above threshold firms compared to below threshold firms. This means that the increase in total network size was more pronounced for above threshold firms post-reform. As a result, we expect the net effect of our instrument, reform period interacted with below-threshold firm type, on network size to be negative.

A priori, the direction of the effect of a change in board composition is ambiguous since the reform only required a change in composition and no adjustment in board size (which we account for directly). As a result, it is possible that firms endogenously adjusted their board composition keeping in mind their choice of networks. In this case, firms would continue to have a choice over their network composition, despite being affected by the exogenous reform. As preliminary evidence against this alternative hypothesis, Panel B of Table 3 compares the average characteristics of below and above threshold companies whose directors were hired post-reform (between 2001 and 2004). If the reform effect is driven by endogenous network selection, one would expect directors to be systematically hired from different 'types' of companies. However, the table shows that the differences in average characteristics are largely statistically insignificant, suggesting that directors were 
hired from similar above and below threshold companies. Hence, there is a priori little evidence to suggest that the reform's effects are driven by differential selection of directors. We address this issue in greater detail in section 4.3.2.

\subsection{EMPIRICAL SPECIFICATION: IV APPROACH}

We first begin by using the complete set of firms in our dataset and implementing an Instrumental Variables (IV) approach. Later, we discuss two more robust identification strategies that account for concerns over endogeneity with the IV approach. However, these robust identification strategies rely only on subsets of the data.

We construct our instrument based on the interaction term, $\left(B_{i} \times R_{t}\right)$, where $B_{i}$ takes the value one if a firm was a below-threshold firm. i.e., their board structure did not meet the requirements as set out in Clause 49 , and $R_{t}$ is a dummy variable taking the value one for years where the reform was applicable, which varies by groups $A, B$, and $C$. We expect the net effect of our instrument on network size to be negative because below-threshold firms experienced a smaller spillover effect and, as a result, a smaller increase in their network size than above-threshold firms. This gives us the following estimation equations:

$$
\begin{gathered}
N_{i t}=\alpha^{I T T}\left(B_{i} \times R_{t}\right)+\gamma^{f} x_{i t-1}+\mu_{i}^{f}+\zeta_{t}^{f}+\eta_{i t} \\
y_{i t}=\beta \widehat{N}_{i t}+\gamma x_{i t-1}+\mu_{i}+\varsigma_{t}+u_{i t}
\end{gathered}
$$

Equation 2 predicts corporate network size $N$ of firm $i$ at time $t$ using the interaction term $\left(B_{i} \times R_{t}\right)$, firm-specific characteristics $x_{i t}$, including the proportion of non-executives in a given year, as well as firm fixed effects $\left(\mu_{i}\right)$ and time dummies $\left(\varsigma_{t}\right)$. The firm-fixed effects capture the systematic time-invariant difference between the above and below-threshold firms $\left(B_{i}\right)$. The proportion of non-executives in a given year $\left(R_{t}\right)$ and time dummies explicitly capture the direct effect of board composition (related to the executive/non-executive ratio) and the corporate governance reform on firm patenting and R\&D. As a result, we 
are able to control separately for the direct effects that each of the two terms in our instrument could have on the dependent variable and exploit only their interactive effect. We also control for the total board size of each firm. Equation 3 uses predicted network size $\hat{N}$ to estimate the impact of corporate network size on firms' R\&D or patent filings, $y_{i t} \cdot{ }^{23}$ The ITT superscript emphasizes the fact that this specification estimates the intent-to-treat (ITT) effect, that is, the effect of eligibility for treatment on outcomes after the reforms came into effect. This means that it estimates the reduced form effect of the reform on network size, even if some firms did not comply with the reform or complied at a later period. ${ }^{24}$

The specifications for all outcome variables are estimated using OLS. For R\&D expenditure, we note that there is a sizeable fraction of firms that do not undertake any R\&D spending. Ideally this calls for the implementation of a Tobit specification that takes into account the left-sided censoring. However, our IV approach relies on a within-transformation to accommodate the firm fixed effect that rules out using a Tobit estimator. ${ }^{25}$ We are nevertheless able to accommodate the firm fixed effect using firm dummies in the other empirical strategies discussed below, which require only a subset of the firms for identification.

\subsection{Alternative IDEnTification Strategies}

The instrumental variable approach discussed so far rests on the the assumption that variation in network size comes exclusively from board adjustments made by below threshold firms (i.e. companies to which the reform applies and that have a proportion of independent

\footnotetext{
${ }^{23}$ We focus on a linear specification because non-linearities in the effect of network size on R\&D and patenting are unlikely given the fact that the size of the board of directors (and hence network size) is limited to relatively low numbers (the median board size in our sample is 7 and the maximum 31).

${ }^{24} \mathrm{An}$ ITT analysis is based on the initial treatment assignment and not on the treatment eventually received. The ITT analysis contrasts with the as-treated (AT) analysis where participants are classified based on the treatment actually received, the difference between the two lying in the treatment of subjects who do not comply. For example, if people who have a serious problem tend to drop out of a study at a higher rate, even a completely ineffective treatment may appear to be providing benefits if one merely compares the condition before and after the treatment for only those who finish the study (see for example Little et al. (2009)).

${ }^{25}$ Using firm dummies in our IV strategy is subject to the incidental parameter problem common to nonlinear models (Greene, 2004).
} 
directors below the threshold mandated by the reforms before the reforms become effective) after the reforms became effective. One potential concern with this approach is that companies that are below and above the critical threshold before the reforms, differ in terms of time-varying unobservable characteristics (for example, in the quality of their R\&D) that are correlated with network size and not accounted for by covariates $x_{i t}$ and firm-fixed effects $\mu_{i}$ (see for example Coles et al. (2008)).

In this sub-section, we describe two robust identification strategies that relax the unconfoundedness assumption required to identify the network effect from differences in the changes of network size between companies below and above the threshold, before the reforms become effective.

\subsubsection{Regression DiscontinUity DeSign}

First, we use a regression discontinuity approach that identifies the effect of the reforms on network size from comparisons between companies arbitrarily close to the critical board composition threshold. This approach has also the advantage that we can account directly for the criteria that jointly determine whether firms were expected to adjust their board structure: the net worth of the firm and the proportion of non-executives on their board at a given point of time. ${ }^{26}$ Treatment is therefore defined based on the interactions of these two threshold variables, that is, the interaction of whether a firm was above the requirement in terms of board composition and whether it was eligible for compliance in terms of its net worth.

We denote $P R O P_{i t}$ as the observed proportion of non-executives on firm i's board (normalized to zero at the threshold equal to 0.5) at time $t$. As in the IV approach in Equation 2 , the binary variable $B_{i t}$ indicates whether the firm was below the required board composition criteria and was therefore required to adjust. Note that in contrast to Equation

\footnotetext{
${ }^{26}$ As mentioned in Section 2, firms with a paid-up share capital of of at least INR 3 crores (US\$ 0.66 million), i.e. groups A, B, and C, were expected to comply by March 31, 2003. In addition, only those firms with a below 50 percent proportion of non-executives on their boards were required to adjust.
} 
2, $B_{i t}$ is now time-varying. ${ }^{27}$ The second continuous forcing variable is denoted as $S C_{i}$, which is the amount of paid up share capital for a given firm $i$. We create two binary variables, $S C_{i}^{A}$ and $S C_{i}^{B}$ which indicate whether a firm was classified as a group $A$ or a group $B$ firm. ${ }^{28}$ In addition to the binary instruments, $\left(B_{i t} \times S C_{i}^{A}\right)$ and $\left(B_{i t} \times S C_{i}^{B}\right)$, we include each variable on its own in the instrument set. As in Cellini et al. (2010), we keep all companies in the sample but account for the distance to the treatment thresholds by including a set of polynomials for the 'running' threshold variables, net worth $\left(S C_{i}\right)$ and proportion of non-executives $\left(P R O P_{i t}\right)$, as well as polynomials of their joint effect $\left(P R O P_{i t} \times S C_{i}\right)$. The first-stage therefore is specified as:

$$
\begin{gathered}
N_{i t}=\alpha_{1}^{I T T}\left(B_{i t} \times S C_{i}^{A}\right)+\alpha_{2}^{I T T}\left(B_{i t} \times S C_{i}^{B}\right)+\alpha_{3}^{I T T}\left(P R O P_{i t}\right)+\alpha_{4}^{I T T}\left(S C_{i}^{A}\right)+\alpha_{5}^{I T T}\left(S C_{i}^{B}\right) \\
+f_{B}\left(P R O P_{i t}, \gamma_{1}\right)+f_{S C}\left(S C_{i t}, \gamma_{2}\right)+f_{B, S C}\left(P R O P_{i t} \times S C_{i}, \gamma_{3}\right)+\varsigma_{t}+\eta_{i t}
\end{gathered}
$$

Again, the ITT superscript highlights the fact that this specification estimates the intentto-treat (ITT) effect. ${ }^{29}$ Note, that our framework relies on the interactive effect of two forcing variables, both continuous, and not just on the discrete support of the number of non-executive directors. To illustrate, our framework allows for comparing firms that have for example, $49 \%$ non-executives on their board to those that have 51\%. Alternatively, we could also compare, for example, two firms that both have $49 \%$ non-executives in their board but one that is just below the eligibility requirement (of paid up share capital US $\$ 2.22$

\footnotetext{
${ }^{27} \mathrm{~A}$ potential concern with allowing $B_{i t}$ to vary over time is that firms might bunch around the threshold. In view of this, as a robustness check, we also estimate the regression discontinuity specification keeping $B_{i}$ fixed at its pre-reform value as in the IV approach. This means that we only estimate the network size effects for firms near the threshold before the reform became effective. Our results are very similar to those reported in Table 7, the main difference being that they are estimated over a smaller sample of firms.

${ }^{28}$ The reason for not using Group C firms as an instrument is that there is a potential concern about their innovative capacity. This strategy, in fact, aids our identification because, in general, we find that Group C firms innovate far less but witness a higher increase in their network and board size which contributes to extra noise in our estimation.

${ }^{29}$ For more discussion on the distinction between ITT and treatment on the treated (TOT) effects within this regression discontinuity framework, see Khanna and Palepu (2000).
} 
million) and the other that is just above. Overall the two criteria provide us with a rich source of variation with which to identify the endogenous network effect.

\subsubsection{Above-Threshold Difference-In-Differences APProach}

Our second alternative identification strategy relies on the fact that a subset of listed firms already satisfied the board structure requirements introduced by Clause 49. These firms, therefore, did not change their board structure as a consequence of the reform (abovethreshold firms). Some of them nevertheless experienced a change in their network size. As we show above, this change in network size was due to directors serving on their boards being hired by other firms that had to adjust their board structure to comply with Clause 49 (below-threshold firms). For these below-threshold firms, the reform led directly to a change in network size. However, we do not rely on the variation in network size induced by the need to adjust a company's board structure. Instead, we rely on the variation in network size among above-threshold firms that resulted from their directors being hired to occupy board seats of below-threshold firms. This variation is exogenous to the choice of network size for above threshold firms.

To operationalize this approach, we perform a simple difference-in-differences estimation comparing above-threshold firms that were affected by the reform as a result of the spillover effect to those that were not. As noted above, Figure 1 illustrates the different types of firms and our empirical strategy for this sample. Both above and below-threshold firms experienced an increase in network size from two effects: hiring new directors and spillover effects from exisiting directors joining other firms. In Section 4.1 we have shown that the difference between hiring/firing policies of above- and below-threshold firms is statistically insignificant. Hence, the relative changes in network size between these two types of firms is likely to be driven entirely by the spillover effect with above-threshold firms experiencing a large spillover effect, and as a result, a larger increase in their network size, compared to below-threshold firms. In this approach, we examine the effect of network 
size on firm outcomes, driven entirely by spillover effects, net of hires and fires. As discussed above, this approach allows us to address concerns that companies' hiring decisions following the broad restructuring reform are endogenous.

To implement our empirical methodology, we keep only the sample of above-threshold firms that did not hire or fire any director during a period of three years post the reform ('ATNo Hire/fire' in Figure 1). This allows us to rule out any hiring or firing based explanation for our result. Within this subset, we compare firms that experienced an increase in their network size, denoted as 'Treatment' firms (Figure 1), to firms that saw no change in their network size, denoted as 'Control' firms (Figure 1). Denoting, $T_{i}$ and $\tilde{R}_{t}$ as dummy variables taking the value one for treatment firms and the three-year period following the reform respectively, we write our specification as:

$$
y_{i t}=\beta\left(T_{i} \times \tilde{R}_{t}\right)+\omega \tilde{R}_{t}+\mu_{i}+\varsigma_{t}+u_{i t}
$$

where $y_{i t}$ is defined as in the equations above. Note that the fixed effect $\mu_{i}$ captures the baseline differences between treatment and control firms.

\section{RESUlTS}

\subsection{BASELine Results}

We first report the instrumental variable results using the methodology outlined in section 4.2. Table 4 reports both OLS and IV results when using total R\&D expenditure as the dependent variable. All specifications include firm and time fixed effects. Standard errors are clustered at the company-level. Column (1) reports the OLS fixed effects results ignoring the potential endogeneity of the network size measure. Columns (2)-(5) show the results from exploiting our identification strategy, that is, when we instrument network size through the difference-in-differences specification. The first-stage results for predicting a firm's network 
size are shown in column (2).

The interaction term in column (2) is statistically significant at the 1 percent level and has a negative sign, that is, network size is negatively related to the number of interlocks for below-threshold firms after the reform. A priori, the direction of the effect of a change in board composition is ambiguous since the reform only required a change in composition and no adjustment in board size (which we account for directly). ${ }^{30}$ As shown in Section 4.1, the negative sign is explained by the fact that the network size gain to firms from existing directors' interlocks is larger for above threshold firms compared to below threshold firms.

Columns (3), (4), and (5) report our IV second stage results using our instrumented network size from column (2). In column (3), the coefficient on instrumented network size increases to 0.491 and is still statistically significant. Columns (4) and (5) of Table 4 break out total R\&D expenditure into current and capital expenditure. Capital R\&D expenditure is incurred on expenses related to machines and equipment whereas current R\&D mostly concerns expenses related to R\&D labor, such as salaries of scientists, technicians, and other personnel. Importantly, current $R \& D$ is fully expensed in the period in which it is incurred whereas capital R\&D is amortized over time just as regular physical capital investment. As such, this distinction allows us to investigate in more detail how interlocks affect firms' R\&D investment decisions. We find a statistically significant effect of network size only on current but not on capital R\&D expenditure. Note that in our sample, on average, capital R\&D accounts for only slightly more than 20 percent of a firm's total R\&D expenditure. This finding suggests that the observed increase in R\&D expenditure is due to an increase in the number of R\&D personnel. This is consistent with the hypothesis that boards suggest new directions for the firm to explore.

It is also interesting to note the differences between the OLS results and the IV results. The magnitude of the effect of network size on innovation is almost seven times that pre-

\footnotetext{
${ }^{30}$ For the instrument to be informative, the direction of the correlation between the instrument and our endogenous variable $N_{i t}$ is irrelevant.
} 
dicted by the OLS regression (the 'naive' OLS estimate on total R\&D expenditure is 0.072 whereas the IV estimate is 0.491 ), offering a potential explanation as to why these effects have not been documented before. This implies that the effect of network size on innovation is biased downward when we ignore the endogeneity of network size. One reason for finding a downward bias in the OLS estimates is that selection related unobservables could be negatively correlated with the outcome. For instance, an average performing firm (in terms of R\&D or patenting) may strategically link more with other firms to take advantage of positive network externalities. This firm will have a large network size despite the fact that its own outcome is low. In this way strategic responses, as unobservables, could be positively correlated with the network size while being negatively correlated with own outcome values. Results from an OLS specification will therefore tend to underestimate the endogenous network effect.

The difference between the OLS and IV results is also economically important as a 1 unit increase in network size leads to a 0.07 unit increase in R\&D spending according to the OLS estimates whereas the IV estimates suggest a 0.49 unit increase. The average 0.49 unit increase in R\&D spending for a 1 unit increase in network it corresponds to an INR 9 million (approximately US\$ 200,000) increase in R\&D spending, which is a reasonable economic magnitude. The biased estimate from the naive OLS approach, in contrast, would imply an economically negligible effect of network size on R\&D spending.

Table 5 reports the results for our second dependent variable, the firms' patent filings. As in Table 4, we report both the OLS results from a 'naive' specification ignoring network endogeneity and from the IV specification discussed in Section 4. A comparison of the naive and IV specifications again reveals a severe downward bias in the coefficient associated with network size if we ignore network size endogeneity. The coefficient from the IV specification shown in Column (3) is 0.092 (while the OLS coefficient is 0.013), but is not statistically significantly different from zero. Columns (4) and (5) break this effect up into international (EPO and USPTO) and domestic patent filings. Patents are national rights; in order to ob- 
tain protection, for example, in India and the U.S., a firm has to obtain patent protection in both jurisdictions separately. ${ }^{31}$ Commonly, if firms obtain patent protection, they do so first (and often exclusively) in their home country which tends to be the focus of their business. Obtaining patent protection abroad is usually more expensive since often the services of foreign patent agents are needed and in our setting, fees are a lot more expensive at the U.S. and European patent offices than at the Indian patent office. By distinguishing between Indian and foreign filings, we ask whether interlocks affect where firms obtain patent protection, which is informative about changes in firms' patenting strategies. The results indicate that only the effect on filings abroad is statistically significant, with a coefficient of 0.042 . The coefficient associated with domestic filings is not statistically different from zero. This suggests that firms respond to new information obtained from more interlocks by filing for patent protection abroad, which suggests that interlocks affect firms' patenting strategies. We explore this effect further in Section 5.4 below. The results for the other covariates do not differ significantly from the R\&D specification shown in Table 4.

Clause 49 mandated that at least half of the board be composed of non-executive directors. This suggests that any increase in the number of interlocks that followed from the reform for below-threshold-firms should have come from new non-executive directors. In the case of above-threshold firms, the increase in interlocks could come from both their sitting executives and non-executives being hired to sit on below-threshold-firms. It is also conceptually important to differentiate the two because executives and monitoring and advising board members may have quite different tasks, duties, and influence. To investigate whether there are different network effects from interlocks arising from executives vs. nonexecutives, we split our network size variable into those interlocks that are formed when an executive of a target firm sits on other boards ('Network Size, Executive') and interlocks that are formed when a non-executive ('Network Size, Non-Executive') of a target firm sits on other boards. Table 6 reports these results for current R\&D and international patent fil-

\footnotetext{
${ }^{31}$ Appendix D provides background information on the Indian patent system.
} 
ings. The columns for each dependent variable are split by whether the interlock is driven by executives or non-executives. We find that coefficients on the network size variable are largely similar across both types of interlocks. Networks formed by executives appear to have a slightly larger effect on international patenting compared to those formed by nonexecutives, but the difference in magnitude does not appear large enough to draw any robust conclusions.

\subsection{Regression Discontinuity Design AND Above-Threshold DiD Re- SULTS}

As discussed in Section 4.3, there is still the possibility that companies below and above the critical threshold before the reforms differ in unobservables that are not absorbed by firmlevel fixed effects. To address this concern, Table 7 shows the estimates obtained from using the regression discontinuity approach specified in Equation (4). The results are qualitatively very similar to the results reported from the IV approach in Table 4 and Table 5.

Since we use a Tobit specification for all outcomes related to R\&D expenditure, we are able to interpret all effects as applicable for the entire sample of firms, rather than just for firms that spend a positive amount on R\&D. When relying on the regression discontinuity approach, both current and capital R\&D expenditure and the coefficient on total R\&D expenditure are statistically significant. While the coefficients on R\&D are not strictly comparable to the IV approach due to the differences in estimators, our estimates for the regressions with patent filings as the dependent variable are very similar in magnitude to the IV results. For total patent counts, the estimate is 0.084 (for IV 0.092), for domestic filings 0.053 (for IV 0.050), and for international filings 0.031 (for IV 0.042). Interestingly, we now also find a statistically significant coefficient on domestic patent filings.

Finally, we examine the impact of the number of interlocks on firms' innovative efforts using our above-threshold difference-in-differences strategy (see Section 4.3.2). Figure 2 plots the average current R\&D expenditure for above-threshold-firms that experienced a 
change in interlocks and those that did not before and after the reforms. The figure shows that before the reforms became effective, the common trends assumptions required by our approach appears to hold. If anything, the treatment group experiences a slight drop before the reforms. However, following the reforms, the average R\&D expenditure of treatment firms increases sharply while the average $R \& D$ expenditure among control firms remains unchanged. We report both Tobit and OLS estimates of network size on R\&D and patenting outcomes in Table 8 using our difference-in-differences strategy comparing two types of above-threshold-firms that did not hire or fire directors during a period of three years after the reform was implemented: treatment firms that increased their network size through an existing director and control firms who saw no change to their network size. The dummy variable, Treatment $\times$ Post-Reform measures the overall treatment effect. We find that abovethreshold-firms that experienced an increase in their network size due to a spillover effect of the reform, increase their R\&D expenditure by 0.839 units (Column 1 ) and their international patent count by 0.064 (Column 6).

An additional explanation for our results is that below-threshold-firms preferentially hire directors from above-threshold-firms that are about to make significant increases in R\&D expenses. Hence this would imply that the increases in $R \& D$ expenses for the abovethreshold-firms are not being driven by the new information provided by directors hired by other firms but because these firms were in the process of increasing their R\&D expenses in any case. These future increases will not be picked up by contemporaneous firm-specific characteristics. Hence we include the Tobin's Q (proxied by the M/B ratio) of the abovethreshold-firms as an additional explanatory variable. If the present values of the future growth opportunities are priced by the market, it should be reflected in higher values of Tobin's Q for the above threshold firms whose directors are hired. However, this ratio has no explanatory power in any of the regressions except for columns (2) and (3) where its coefficients have opposing signs. This suggests that the above-threshold-firms whose directors are hired are not substantially different in terms of potential growth opportunities from above-threshold-firms whose directors are not hired. 
To summarize our results so far, increases in network size appear to be positively related to changes in current R\&D expenditure. In addition, firms increase patent filings abroad. Our results for domestic filings are less clear. We investigate potential mechanisms behind these effects in more detail in the next two sections.

\subsection{Unboxing Network Size: Peer Effects in Research Activity}

In this section, we investigate a potential mechanism behind the observed positive effect of network size on R\&D spending and patenting. Specifically, we investigate whether the effect can be (at least partly) explained by peer effects, that is whether R\&D spending and patenting by companies $j=1, \ldots, J$ that are linked to company $i$ through board interlocks affect company $i$ 's own R\&D spending and patenting. In other words, we test whether increased $R \& D$ expenditure and more patenting by firm $i$ following the board structure reform can be explained by average R\&D expenditure and patenting by companies that share an interlocked director with firm $i$. We further refine this analysis by taking into account the technological proximity between firms $i$ and $j$.

The identification of such peer effects encounters well known problems laid out in Manski (1993). In general, three effects need to be distinguished in the analysis of peer effects. The first type of effect is an endogenous effect which arises from a firm's propensity to behave in some way as a function of the behavior of the group. This represents the effect that other firms' R\&D spending and patenting has on a firm's own R\&D investment and patenting decisions - which is our main interest here. The second is a so-called contextual effect which represents the propensity of a firm to behave in some way as a function of the exogenous characteristics of its peer group. For example, pharmaceutical companies may be more likely to invest in R\&D and to patent. The third type is a correlated effect which arises due to factors that are common amongst firms belonging to the same group, which compel them to behave in a similar manner. This effect can, for example, arise due to common shocks that affect all firms in a peer group. 
Our main focus lies in estimating endogenous peer effects, owing to their capacity of generating social multiplier effects. ${ }^{32}$ To address the identification problem inherent in the estimation of endogenous effects, we use variation in peer $R \& D$ spending and patenting coming from the board restructuring reform. Specifically, we restrict our analysis to the sample of treatment and control above-threshold-firms as defined in section 4.3.2. As noted previously, the board restructuring reform affected the treated above-threshold-firms by increasing their network size, while keeping the network/peer-group size of control firms unchanged. As a result, we expect a change in the average peer group R\&D and patenting of treatment firms relative to control firms after the board restructuring reform. A priori, this change could be positive or negative depending on the type of firms that join the peer group of treatment firms after the reform.

Our set of estimating equations, based on the reduced form Equation (5), are as follows:

$$
\begin{gathered}
\bar{y}_{i t}^{N}=\beta^{f}\left(T_{i} \times \tilde{R}_{t}\right)+\omega^{f} \tilde{R}_{t}+\mu_{i}^{f}+\varsigma_{t}^{f}+u_{i t} \\
y_{i t}=\widehat{\bar{y}}_{i t}^{N}+\omega \tilde{R}_{t}+\mu_{i}+\varsigma_{t}+u_{i t}
\end{gathered}
$$

where $\bar{y}_{i t}^{N}$ is the average peer group outcome for firm $i$ at time $t$. All other variables are as defined in section 4.3.2. Our identification strategy relies only on exogenous variation that induced a shift in the network size, and therefore composition, of firm i's network. Therefore, we expect that the board restructuring reform affects firm outcomes indirectly by changing the peer group size and composition of treated firms. Our IV estimates have a LATE (Local Average Treatment Effect) interpretation since our instrument only identifies the requisite variation for firms that experienced some spillover effects due to the reform.

Table 9 shows the corresponding results. Panel A of the table reports the first-stage

\footnotetext{
${ }^{32}$ For a more general overview of the many problems encountered in estimating peer effects and different methods proposed for their estimation see Epple and Romano (2011).
} 
results. We find that the board restructuring reform had a positive effect on average peer outcomes for above-threshold treatment firms who witnessed an increase in their network size on behalf of their directors joining other boards. The treatment increased average network R\&D by 1.603 units and average network patent counts by 0.248 units. Panel B reports the second-stage results using the reforms as an instrument for average network outcomes. For each outcome in the table, we also report the first-stage F statistic to provide an assessment of how strong our instrument is. Throughout, our first-stage F statistics lie well above 10, indicating that we do not encounter a weak instrument problem. We find evidence for strong, positive, and significant peer effects for international patenting behavior and current R\&D spending.

For $R \& D$, the estimates indicate strong positive peer effects. We find that a 1 unit increase in average network R\&D increases the target firm's own R\&D by 0.193 units (Column 1). The R\&D effect is driven by the response to peer activity in current R\&D spending (Column 2). Capital expenditure, which tends to be inelastic and is relatively difficult to adjust in the short run, is unaffected by average (capital) R\&D of peer firms (Column 3). Our results therefore reflect only the short-run effects of networked peer firms on own firm research activity. ${ }^{33}$ Similarly, a 1 unit increase in average network patent count increases the target firm's own patent count by 0.528 units (Column 4). This effect is driven entirely by a response to peer activity in international patenting (Column 6) as we find no significant peer effects for domestic patenting (Column 5).

To refine this analysis, we weight interlocks according to firms' technological proximity measured using the technology classes reported by firms' patent filings. We follow (Balsmeier et al., 2014a) and create three different proximity measures using 3-digit IPC codes:

\footnotetext{
${ }^{33}$ We also estimate the R\&D specifications using Tobit. The corresponding results indicate positive but statistically insignificant peer effects. Hence the comparison between the OLS and Tobit estimates suggest that R\&D peer effects shown in Columns (1)-(3) of Table 9 operate at the intensive rather than the extensive margin; i.e. it is firms already engaging in $R \& D$ that increase their expenditure in response to positive peer activity.
} 
1. A binary variable that is equal to one if two interlocked firms have patented in at least one common IPC category at the 3-digit level;

2. The fraction of 3-digit IPC classes in which two interlocked firms have both patented;

3. The Jaffe (1986) measure of technological proximity. ${ }^{34}$

Table 10 shows the results for the Jaffe measure, which is our preferred measure of technological proximity. It is a continuous variable that varies between zero and one which captures the similarity of interlocking firms' entire patent portfolios in terms of their technology classes. The other two measures capture technological proximity less precisely. We see in Table 10 that the overall pattern of results is very similar to that shown in Table 9 . However, the coefficients on current R\&D and patenting are larger, especially those on international patenting. We show the results for the other two similarity measures in Tables B2 and B3 in the appendix. The two alternative proximity weights produce very similar estimates compared to Table 10. Note that as expected, the binary similarity measure in Table B2 produces slightly smaller coefficients than the other two measures. Overall, the results that use technological proximity to weight firms' network size indicate that firms benefit more from interlocking directors, the closer they are in the technology space.

\subsection{Distinguishing the InNovation EfFect from the Strategic EF-}

\section{FECT}

Since the preceding section showed that there are positive effects of an increase in interlocks on a firm's R\&D and patenting through peer activity and that effect increases in technological proximity, we next further decompose the mechanisms of these peer effects. We are

${ }^{34}$ The Jaffe correlation coefficient is computed as follows:

$$
J_{i j}=\frac{F_{i} F_{j}^{\prime}}{\sqrt{\left[\left(F_{i} F_{j}\right)\left(F_{i j}\right)\right]}}
$$

where $F_{i}$ and $F_{j}$ are vectors that contain the number of patents filed in any of the IPC 3-digit classes by firms $i$ and $j$, respectively. $J_{i j}$ assumes values between one and zero, according to how much vectors $F_{i}$ and $F_{j}$ overlap. 
particularly interested in investigating the differential effect of interlocks on domestic vs. international patenting. Theoretically, an observed increase in patenting can be explained by both an innovation and a strategic effect. There are two types of innovation effects. The first arises from the transmission of genuinely new knowledge that allows a firm to conduct new research or modify existing processes/products in a way that leads to patentable outcomes. The second arises when a board interlock provides information that leads to innovation. This situation could arise if, for example, a shared director informs the board of the importance of conducting a certain type of R\&D (or on a certain technology). Both types of innovation effects are observationally equivalent because they both imply that the company does not patent an existing invention. In contrast, the strategic effect arises from a situation in which a firm decides to patent an existing invention because of information obtained through a board interlock. This may happen, for example, if a shared director informs a board about the patenting activities of another company on whose board she also sits. The innovation effects can be distinguished from the strategic effect because the strategic effect implies that the company already possesses a patentable invention which it had previously not patented.

Our results shown in Table 4 using the firm's R\&D expenditure as the dependent variable suggest that board interlocks and hence network size impact a firm's innovative activity. These results provide evidence in favor of an innovation effect - a result reinforced by our finding that the positive effect applies mainly to current expenditure on R\&D. The results in Table 5, however, are more difficult to interpret because, in principle, innovation as well as strategic effects could give rise to the observed positive impact of network size on patent filings. One way to interpret our results is to acknowledge the implicit timing assumptions made in our analysis. Since we look at contemporaneous effects of network size on patenting, it is difficult to imagine that firms are able to respond so quickly to the transmission of new knowledge to lead to an immediate filing of a patent on a new invention. The contemporaneous link between the increased flow of information and patenting is more likely to be the result of the patenting of existing inventions. The finding in Table 5 that the change 
in network size affected only international patent filings reinforces this notion. To investigate this issue further, we analyze patenting along three additional dimensions. First, we estimate the impact of network size on patenting propensities directly. Second, we exploit information on patent families to gauge the effect on a firm's propensity to file an additional patent on an existing invention. Third, we use patent citations to weight patent filings and hence account for heterogeneity in the value of patents. If additional international patent filings are triggered by a shift in patenting strategy induced by interlocks, it is likely that these patents are not particularly valuable from a technological point of view. Hence they would attract fewer forward citations by subsequent patents. Note that the analysis of patent citations is limited to international patent filings since patent citations are not available in an electronic format for Indian patent filings. In our setting, this is not an important limitation since our focus is on explaining and interpreting the positive effect of interlocks on international patent filings shown in Table 5.

Table 11 reports results when using the ratio of patent counts to $R \& D$ - a firm's patenting propensity - as the dependent variable. This ratio provides a measure of the number of patents for a given amount of R\&D expenditure and allows us to gauge the effect of interlocks on patenting behavior while accounting for potential changes in R\&D expenditure (Hall and Ziedonis, 2001). The results in Column (2) from our difference-in-differences specification indicate a positive and statistically significant effect of network size on a firm's overall patenting propensity. Columns (3) and (4) break this up again into domestic and international filings. The estimates confirm the results shown in Table 5. The change in network size affects only the propensity to file a patent abroad. This suggests that an increase in corporate network links through interlocking boards impacts on patenting by raising a firm's international patenting propensity, which reflects a strategic effect.

To investigate specifically whether information transmission through board interlocks triggers firms to patent existing inventions, we construct an indicator variable that is equal to one if a firm files a patent application that is an equivalent of a previously filed patent 
application. ${ }^{35}$ For example, the indicator is equal to one if a firm files in 2003 a patent application with the EPO for which it has already filed a domestic patent application in 2002 with the Indian patent office. This indicates that the firm is not filing a patent on a new invention, but merely decides to also patent a given invention in another jurisdiction. We add this variable to our specification and interact it with our measure of network size. The corresponding results are shown in Table 12. When we add the 'previous equivalent' dummy variable to our specification, we find the corresponding estimated coefficient to be large and negative, albeit statistically significant only in column (3). As would be expected, these estimates suggest that if a firm has already patented a given invention, the likelihood of patenting a related invention is reduced considerably. Columns (1)-(3) show results for total, domestic and foreign patent filings when we interact the equivalent dummy variable with our measure for network size. This specification tests whether the increase in network size impacts a firm's patent filing behavior due to strategic considerations which is reflected in the firm's decision to patent an existing invention (as indicated by the previous patent filing). The interaction term is positive across all three specifications, but statistically significant only in the case of foreign filings. This indicates that an increase in network size indeed leads to the filing of a foreign patent on an existing invention.

Finally, in Table B4 in the online appendix, we focus on foreign patent filings and use forward citations to weight patent filings. There is a large literature that suggests that forward citations serve as a proxy for the value of patents (Trajtenberg, 1990; Hall et al., 2005). Therefore, if the positive effect on foreign patent filings due to an increase in network size is indeed driven by strategic considerations triggered by new interlocks, there is no reason to expect that these filings would attract a larger number of forward citations. Table B4 shows that if we weight patent filings abroad by forward citations (we use different time windows during which patents can accumulate citations), the coefficient on network size is

\footnotetext{
${ }^{35}$ Because patents are national rights, to obtain patent protection, patents have to be obtained in each jurisdiction separately in which patent protection is sought. Patents on the same invention in different jurisdictions are referred to as equivalents.
} 
no longer statistically significant.

To sum up, our results paint a consistent picture. They suggest that the positive effect of network size on foreign patenting found in Table 5 is mainly the result of a firm's strategic response to new information. Hence, these results indicate the presence of a strategic effect from interlocking boards of directors on patenting behavior.

\section{ConCLUSIONS}

In this paper, we investigate if increases in the size of networks spanned by interlocked directors across firms increase innovative and patenting behavior among firms. We find that they do. To tackle the endogeneity inherent in determining firms' network sizes, we exploit a corporate governance reform introduced between 2001 and 2003 that forced a subset of Indian firms to restructure their boards of directors. The restructuring led to a substantial change in the size of corporate networks. The comparison of companies forced to restructure with companies that were not, allows us to identify the effect of network size on $R \& D$ spending and patenting.

We find that current $R \& D$ expenditure is significantly positively related to changes in the size of the firm's network of directors. We interpret this as an innovation effect that arises as a consequence of the information transmitted via shared directors. We show that the innovation effect is driven by peer effects, i.e., a positive association of R\&D spending by companies within corporate networks. We also find that the number of patent filings increases significantly following a board restructuring. We show that this is the result of a strategic effect, that is, firms file more patents on existing inventions after obtaining information of strategic value through directors that sit on other (potentially) competing firms' boards of directors. Interestingly, this strategic effect impacts Indian companies' decisions to file patents abroad (at the EPO and USPTO). In other words, an exogenous increase in network size significantly increases the probability that the firm extends the geographical 
scope of patent protection by filing a foreign patent application on an existing invention.

Overall, we find substantial non-market mediated effects on research and patenting activity between firms, induced through the sharing of board members across companies. Our evidence suggests that shared directors serve as a channel for the transmission of information across companies which impacts both their innovative as well as strategic patenting behavior. Future research could investigate the impact of these innovation and strategic effects on company performance.

\section{ACKNOWLEDGEMENTS}

We would like to thank the editor and two anonymous referees for their very constructive feedback which has greatly improved the paper. We also thank Cláudia Custódio, Naveen Daniel, Ming Fang, Bronwyn Hall, Gimmy Moore, Lalitha Naveen, Georg von Graevenitz, Subrata Sarkar, and seminar participants at the 2013 IGIDR Emerging Markets conference, the 2014 European Finance Association Meetings, the 2014 Financial Management Association meetings, the 8th Conference on Micro Evidence on Innovation and Development (MEIDE), Cyprus University of Technology, IIM Bangalore, LMU Munich, NSE India, and the Universidad Carlos III Madrid for helpful comments. 


\section{REFERENCES}

Arora, A., L. Branstetter, And C. Chatterjee (2011): "Strong Medicine: Patent Reform \& the emergence of a Research-Driven Pharmaceutical Industry in India," in The Location of Biopharmaceutical Activity, ed. by I. M. Cockburn and M. J. Slaughter, NBER.

Arora, A., L. Branstetter, C. Chatterjee, And K. Saggi (2009): "Strong Medicine? Patent Reform and the Transformation of the Indian Pharmaceutical Industry," mimeo.

AudREtSCH, D. AND M. FELDMAN (1996): "R\&D Spillovers and the Geography of Innovation and Production," American Economic Review, 86, 630-640.

BALDWIN, R. AND W. Gu (2004): “Trade Liberalization: Export-Market Participation, Productivity Growth and Innovation," Oxford Review of Economic Policy, 20, 372ÃćâĆňâĂIJ392.

BAlsmeier, B., A. Buchwald, AND J. Stiebale (2014a): "Outside directors on the board and innovative firm performance," Research Policy, 43, 1800-1815.

BAlSMeier, B., L. Fleming, AND G. MANSo (2014b): "Independent Boards and Innovation,” Unpublished working paper, University of California at Berkeley.

BELENZON, S. AND T. BERKOVITZ (2010): "Innovation in business groups," Management Science, 56, 519-535.

Bertrand, M., P. Mehta, And S. Mullainathan (2002): "Ferreting Out Tunneling: An Application to Indian Business Groups," Quarterly Journal of Economics, 117, 121-148.

Black, B. S. AND V. S. Khanna (2007): "Can Corporate Governance Reforms Increase Firm Market Values? Event Study Evidence from India," Journal of Empirical Legal Studies, 4, 749-796.

Cellini, S., F. Ferreira, AND J. Rothstein (2010): “The Value of School Facility Investments: Evidence from a Dynamic Regression Discontinuity Design," Quarterly Journal of Economics, 125, 215-261. 
Chakrabarti, R., W. Megginson, And P. YadaV (2008): "Corporate Governance in India," Applied Corporate Finance, 20, 59-72.

Chang, S., C. Chung, And I. Mahmood (2006): "When and how does business group affiliation promote firm innovation? A tale of two emerging economies," Organization Science, 17, 637.

Chaudhuri, S., P. K. Goldberg, AND P. JiA (2006): "Estimating the Effects of Global Patent Protection in Pharmaceuticals: A Case Study of Quinolones in India," American Economic Review, 96, 1477-1514.

Coles, J., N. Daniel, And L. NAVeen (2008): "Boards: Does one size fit all?" Journal of Financial Economics, 87, 329-356.

DHARMAPALA, D. AND V. KHANNA (2013): “Corporate governance, enforcement, and firm value: evidence from India," Journal of Law, Economics, and Organization, 29, 10561084.

Do, Q., B. NGUyen, AND R. RAU (2014): "Sugar and spice and everything nice: What are successful independent directors made of?" Unpublished working paper, University of Cambridge.

Epple, D. AND R. Romano (2011): "Peer effects in education: A survey of the theory and evidence," Handbook of Social Economics.

Field, L. AND A. Mkrtchyan (2014): "The Effect of Director Expertise on Acquisition Performance," Unpublished working paper, Penn State University.

FRACASSI, C. AND G. TATE (2012): "External networking and internal firm governance," Journal of Finance, 67, 153-194.

Gomes-CAsseres, B., A. B. JAFFE, AND J. HAgEDOORN (2006): “Do alliances promote knowledge flows?” Journal of Financial Economics, 80, 5-33. 
Greene, W. (2004): "Fixed Effects and Bias Due to the Incidental Parameters Problem in the Tobit Model," Econometric Reviews, 23, 125-147.

Hagedoorn, J., A. Link, AND N. Vonortas (2000): "Research partnerships," Research Policy, 29, 567-586.

Hall, B. H., A. JAffe, And M. Trajtenberg (2005): "Market Value and Patent Citations," The RAND Journal of Economics, 36, 16-38.

HALL, B. H. AND R. ZIEDONIS (2001): “The patent paradox revisited: an empirical study of patenting in the U.S. semiconductor industry, 1979-95," RAND Journal of Economics, 32, $101-128$.

HARFord, J. AND R. J. SCHONLAU (2013): "Does the director labor market offer ex post settling-up for CEOs? The case of acquisitions," Journal of Financial Economics, 110, 1836.

Haunschild, P. R. AND C. M. BeckMan (1998): "When Do Interlocks Matter?: Alternate Sources of Information and Interlock Influence," Administrative Science Quarterly, 43, 815-844.

JAFFE, A. (1986): “Technological Opportunity and Spillovers of R\&D: Evidence from Firms' Patents, Profits, and Market Value," American Economic Review, 76, 984-1001.

JAffe, A., M. Trajtenberg, And R. Henderson (1993): "Geographic Localization of Knowledge Spillovers as Evidenced by Patent Citations," Quarterly Journal of Economics, $108,577-598$.

KALE, D. AND S. LitTle (2007): "From Imitation to Innovation: The Evolution of R\&D Capabilities and Learning Processes in the Indian Pharmaceutical Industry," Technology Analysis \& Strategic Management, 19, 589-609.

Khanna, T. AND K. PAlepU (2000): “Is Group Affiliation Profitable in Emerging Markets? An Analysis of Diversified Indian Business Groups," Journal of Finance, 55, 867-891. 
Kor, Y. And C. Sundaramurthy (2008): “Experience-Based Human Capital and Social Capital of Outside Directors," Journal of Management, 35, 981-1006.

LitTle, R. J., Q. LONG, AND X. LIN (2009): “A comparison of methods for estimating the causal effect of a treatment in randomized clinical trials subject to noncompliance," Biometrics, 65, 640-649.

Mallapragada, G., R. SRinivasan, And S. Wuyts (2015): "Board Interlocks and New Product Introductions," mimeo.

MANSKI, C. (1993): "Identification of endogenous social effects: The reflection problem," Review of Economic Studies, 60, 531.

Martinez, C. (2010): "Insight into Different Types of Patent Families," OECD Science, Technology and Industry Working Papers, 2010/2.

Melitz, M. And D. Trefler (2012): “Gains from Trade when Firms Matter," Journal of Economic Perspectives, 26, 91-118.

Mueller, J. (2006): “The Tiger Awakens: The Tumultuous Transformation of India's Patent System and the Rise of Indian Pharmaceutical Innovation," University of Pittsburgh School of Law Working Paper Series, 43.

OH, W.-Y. AND V. L. BARKER (2015): "I like what I see: CEO outside directorship and strategic imitation in R\&D investment," Unpublished working paper, University of Calgary.

SARKAR, J. (2009): "Board Independence \& Corporate Governance in India: Recent Trends \& Challenges Ahead," Indian Journal of Industrial Relations, 44, 576-592.

Schilling, M. AND C. PhelPs (2007): "Interfirm collaboration networks: The impact of large-scale network structure on firm innovation," Management Science, 53, 1113-1126.

SchWARTZ-Ziv, M. AND M. S. Weisbach (2013): "What do boards really do? Evidence from minutes of board meetings," Journal of Financial Economics, 108, 349-366. 
STERNE, R. AND T. CHAPLICK (2005): "Why directors must take responsibility for intellectual property," Intellectual Asset Management Magazine, 10, 16-24.

STUART, T. E. AND S. YIM (2010): "Board interlocks and the propensity to be targeted in private equity transactions," Journal of Financial Economics, 97, 174-189.

Trajtenberg, M. (1990): "A Penny for Your Quotes: Patent Citations and the Value of Innovations," The RAND Journal of Economics, 21, 172-187.

WIPO (2013): “World Intellectual Property Indicators 2012,” WIPO. 
Table 1: Summary Statistics

This table reports summary statistics of variables used in our regressions for the full sample of firms over the years 2000-2007. The sample consists of 11,358 firm-year observations. Patent data are extracted from USPTO, EPO (PATSTAT version April 2010), EKASWA, iPairs, and BigPatents India. All firm level variables are obtained from the PROWESS database. ${ }^{\dagger}$, all figures reported for these variables are in 10 millions (crores) of Indian Rupees. Only firms listed on the BSE are part of the sample. We report the mean, standard deviation and the range (minimum, maximum) of each variable.

\begin{tabular}{lrrrrr}
\hline \hline & & & & & \\
Variable & Obs & Mean & Std. Dev. & Min & Max \\
& & & & & \\
R\&D $^{\dagger}$ & 11,358 & 0.201 & 0.639 & -0.605 & 6.681 \\
Current R\&D $^{\dagger}$ & 11,358 & 0.167 & 0.566 & 0 & 6.189 \\
Capital R\&D & 11,358 & 0.078 & 0.387 & 0 & 6.458 \\
Total Patent Count & 11,358 & 0.389 & 5.114 & 0 & 240 \\
Domestic Patent Count & 11,358 & 0.281 & 3.887 & 0 & 202 \\
International Patent Count & 11,358 & 0.108 & 1.713 & 0 & 72 \\
Patent Propensity (total) & 11,358 & 0.130 & 1.304 & 0 & 46.415 \\
Patent Propensity (domestic filings) & 11,358 & 0.097 & 1.067 & 0 & 46.415 \\
Patent Propensity (int. filings) & 11,358 & 0.033 & 0.458 & 0 & 22.896 \\
Network Size & 11,358 & 11.700 & 14.196 & 0 & 114 \\
Board size & 11,358 & 7.909 & 3.484 & 1 & 31 \\
Average co-directorships & 11,358 & 1.720 & 0.760 & 1 & 7 \\
Proportion Non-Executive & 11,358 & 0.640 & 0.266 & 0 & 1 \\
Tobin's Q & 11,358 & 0.921 & 7.13 & 0 & 502.83 \\
Assets (log) & 11,358 & 3.998 & 2.169 & -4.605 & 12.020 \\
Exports by sales (log) & 11,358 & 0.099 & 0.201 & -0.009 & 6.917 \\
Industry Patenting Propensity & 11,358 & 0.115 & 0.211 & 0 & 0.836 \\
Business Group Patenting Propensity & 11,358 & 0.057 & 0.608 & 0 & 46.415 \\
& & & & & \\
\hline \hline
\end{tabular}


Table 2: Summary Statistics by category - before and after the reform

This table reports summary statistics of variables used in our regressions for the full sample of firms over the years 2000-2007. We report the mean of each variable and distinguish among 3 dimensions: (1) company Group A, Group B, and Group C, (2) companies below and above the required threshold introduced by the reform, as well as (3) before and after the reform took effect. Patent data are extracted from USPTO, EPO (PATSTAT version April 2010), EKASWA, iPairs, and BigPatents India. All firm level variables are obtained from the PROWESS database. Only firms listed on the BSE are part of the sample.

\begin{tabular}{|c|c|c|c|c|c|c|}
\hline & \multicolumn{3}{|c|}{ Above required proportion } & \multicolumn{3}{|c|}{ Below required proportion } \\
\hline & $\begin{array}{r}\text { Before reform } \\
\text { Mean }\end{array}$ & $\begin{array}{r}\text { After reform } \\
\text { Mean }\end{array}$ & $\begin{array}{r}\text { Difference } \\
\text { t-statistic }\end{array}$ & $\begin{array}{r}\text { Before reform } \\
\text { Mean }\end{array}$ & $\begin{array}{r}\text { After reform } \\
\text { Mean }\end{array}$ & $\begin{array}{r}\text { Difference } \\
\text { t-statistic }\end{array}$ \\
\hline \multicolumn{7}{|l|}{ Group A } \\
\hline $\mathrm{R} \& \mathrm{D}$ & 0.414 & 0.612 & -1.960 & 0.356 & 0.445 & -0.790 \\
\hline Current R\&D & 0.331 & 0.529 & -2.157 & 0.309 & 0.379 & -0.693 \\
\hline Capital R\&D & 0.181 & 0.242 & -0.975 & 0.113 & 0.200 & -1.151 \\
\hline Total Patent Count & 0.338 & 1.216 & -1.398 & 0.469 & 2.072 & -0.971 \\
\hline Network Size & 18.154 & 24.607 & -3.980 & 12.897 & 20.038 & -3.624 \\
\hline Assets (log) & 6.296 & 6.545 & -1.702 & 5.870 & 6.033 & -0.704 \\
\hline Tobin's Q & 0.826 & 0.926 & -1.228 & 1.13 & 0.939 & 0.825 \\
\hline Board size & 10.704 & 11.309 & -1.878 & 9.469 & 9.777 & -0.769 \\
\hline \multicolumn{7}{|l|}{ Group B } \\
\hline $\mathrm{R} \& \mathrm{D}$ & 0.203 & 0.308 & -2.566 & 0.163 & 0.197 & -0.849 \\
\hline Current R\&D & 0.137 & 0.263 & -3.498 & 0.121 & 0.162 & -1.135 \\
\hline Capital R\&D & 0.093 & 0.111 & -0.721 & 0.070 & 0.081 & -0.436 \\
\hline Total Patent Count & 0.372 & 0.378 & -0.043 & 0.114 & 0.239 & -1.156 \\
\hline Network Size & 11.711 & 14.769 & -3.542 & 9.032 & 10.684 & -2.002 \\
\hline Assets (log) & 4.665 & 4.757 & -0.958 & 4.463 & 4.234 & 1.958 \\
\hline Tobin's Q & 0.640 & 0.982 & -2.827 & 0.853 & -1.057 & -1.033 \\
\hline Board size & 8.570 & 8.867 & -1.562 & 7.975 & 7.647 & 1.568 \\
\hline \multicolumn{7}{|l|}{ Group C } \\
\hline$R \& D$ & 0.127 & 0.129 & -0.118 & 0.035 & 0.028 & 1.117 \\
\hline Current R\&D & 0.098 & 0.104 & -0.383 & 0.022 & 0.021 & 0.451 \\
\hline Capital R\&D & 0.042 & 0.044 & -0.188 & 0.012 & 0.009 & 1.060 \\
\hline Total Patent Count & 0.020 & 0.077 & -1.480 & 0.007 & 0.009 & -0.321 \\
\hline Network Size & 7.048 & 9.914 & -6.792 & 3.596 & 6.237 & -7.828 \\
\hline Assets (log) & 3.554 & 3.469 & 1.368 & 2.799 & 2.737 & 1.008 \\
\hline Tobin's Q & 0.504 & 1.185 & -1.560 & 0.541 & 0.742 & -2.658 \\
\hline Board size & 7.399 & 7.690 & -2.674 & 5.598 & 6.370 & -6.986 \\
\hline
\end{tabular}




\section{Table 3: Network Dynamics Around the Reform Period}

Panels A \& B of the table report results on the composition of firm networks around the reform period. Panel A: This panel reports the differences in network size between above and below threshold companies. The sample in Column (1) consists of 3,711 above-threshold and 1,813 below-threshold firm-year observations. The sample in Column (2) consists of 9,447 above-threshold and 4,052 below-threshold firm-year observations. The sample in Column (3) consists of 1,799 above-threshold and 858 below-threshold firms. Columns (1) and (2) report pre and post differences in total network size between above and below threshold companies. Column (3) reports the difference in network size between the post and pre reform periods. This is reported in two ways: the gain in network size to firms from their hires of new directors net of their fires of old directors (Network hires - Network fires); and the gain in network size to firms from those directors that remained in the company (Network remaining). $* *$ Differences are statistically significant at 1\%. Panel B: This panel reports the average firm-level characteristics for firms whose directors were appointed by other firms in the post-reform period. The sample consists of 1,177 above-threshold and 560 below-threshold firms. Figures reported in the table are sample means of these averages across below/above threshold companies and for all years. Mean difference are statistically evaluated using both parametric (t-test) and non-parametric (Wilcoxon-MannWhitney) tests.

PANEL A

\begin{tabular}{|c|c|c|c|c|}
\hline & \multicolumn{2}{|c|}{ Total Network Size } & \multicolumn{2}{|c|}{ Network gain from } \\
\hline & & & hires - fires & remaining \\
\hline & Pre Reform (1) & Post reform (2) & (Post-Pre) $d$ & ference (3) \\
\hline Above Threshold & 7.138 & 12.268 & 0.091 & 4.082 \\
\hline Below Threshold & 5.649 & 10.094 & 0.117 & 3.368 \\
\hline Difference & $1.489^{* *}$ & $2.174^{* *}$ & -0.026 & $0.714^{* *}$ \\
\hline
\end{tabular}

PANEL B

\begin{tabular}{|c|c|c|c|c|}
\hline & \multicolumn{4}{|c|}{$\begin{array}{c}\text { Average pre-reform firm-level characteristics of firms } \\
\text { whose directors were hired post-reform }\end{array}$} \\
\hline & \multirow{2}{*}{$\begin{array}{c}\text { Below required } \\
\text { proportion }\end{array}$} & \multirow{2}{*}{$\begin{array}{c}\text { Above required } \\
\text { proportion }\end{array}$} & \multicolumn{2}{|r|}{ Difference } \\
\hline & & & t-statistic & Wilcoxon z-statistic \\
\hline$R \& D$ & 0.166 & 0.174 & 0.399 & 2.441 \\
\hline Current R\&D & 0.129 & 0.136 & 0.415 & 2.278 \\
\hline Capital R\&D & 0.068 & 0.063 & -0.419 & 2.155 \\
\hline Total Patent Count & 0.135 & 0.140 & 0.077 & -0.086 \\
\hline Domestic Patent Count & 0.101 & 0.117 & 0.350 & -0.086 \\
\hline International Patent Count & 0.033 & 0.022 & -0.577 & 1.777 \\
\hline Patent Propensity (total) & 0.061 & 0.322 & 1.091 & -0.205 \\
\hline Patent Propensity (domestic) & 0.051 & 0.304 & 1.119 & -0.318 \\
\hline Patent Propensity (int.) & 0.009 & 0.018 & 0.558 & 0.918 \\
\hline Assets (log) & 4.065 & 4.064 & -0.010 & 0.373 \\
\hline Tobin's q & 0.789 & 0.502 & -5.974 & -10.563 \\
\hline Exports by sales (log) & 0.101 & 0.088 & -1.464 & 0.098 \\
\hline
\end{tabular}




\section{Table 4: Network Size Effects: R\&D}

This table reports results on the effect of network size on firm research and development (R\&D) expenditure. The sample consists of 11,358 firm-year observations from 2000 to 2007 . The table reports the results from our main regression specification (Equation 2 \& 3). Column (1) reports results from an OLS regression; the dependent variable for this model is total R\&D expenditure. Column (2) reports the first stage of the IV regression where the dependent variable is total network size. Column (3) reports the corresponding second stage; the dependent variable is total research and development expenditure. Columns (4) and (5) report IV second stage results for different components of research and development expenditure: current R\&D (Column (4)) and capital R\&D (Column (5)). All control variables are lagged by one year and include the following: Network Size measures the number of direct links i.e. the number of other firms with whom a given firm shares common directors; Average co-directorships measures how 'busy' firm's board is, i.e, the average number of firms on whose boards each director of the firm serves; Proportion Non-Executives is the proportion of non-executive directors on the board; Tobin's Q is proxied by the M/B ratio; Total assets in logs is total book value of assets; Log Exports/Sales is total exports of the company divided by its total sales; Aggr. Industry Patents is the aggregate patents count normalized by R\&D expenditure within each industry; Aggr. Business Group Patents is the aggregate patents count normalized by R\&D expenditure within each business group. Standard errors clustered by firm are reported in parentheses. * indicates significance at $10 \%$; ** at 5\%; *** at $1 \%$.

\begin{tabular}{|c|c|c|c|c|c|}
\hline \multirow{3}{*}{ Dep Var: } & \multirow{3}{*}{$\begin{array}{c}\text { OLS } \\
\text { R\&D } \\
(1)\end{array}$} & \multirow{3}{*}{$\begin{array}{c}\text { IV } 1^{\text {st }} \text { stage } \\
\text { Network Size } \\
(2)\end{array}$} & \multicolumn{3}{|c|}{ IV $2^{\text {nd }}$ stage } \\
\hline & & & $\mathrm{R} \& \mathrm{D}$ & Current R\&D & Capital R\&D \\
\hline & & & (3) & (4) & (5) \\
\hline Network Size & $\begin{array}{l}0.072^{* *} \\
(0.034)\end{array}$ & & $\begin{array}{c}0.491^{*} \\
(0.256)\end{array}$ & $\begin{array}{c}0.314^{*} \\
(0.180)\end{array}$ & $\begin{array}{c}0.177 \\
(0.131)\end{array}$ \\
\hline Reform $\times$ Below Threshold & & $\begin{array}{c}-2.101^{* * *} \\
(0.454)\end{array}$ & & & \\
\hline Board size & $\begin{array}{c}0.008 \\
(0.045)\end{array}$ & $\begin{array}{c}0.435^{* * *} \\
(0.053)\end{array}$ & $\begin{array}{c}-0.176 \\
(0.115)\end{array}$ & $\begin{array}{c}-0.122 \\
(0.084)\end{array}$ & $\begin{array}{c}-0.053 \\
(0.047)\end{array}$ \\
\hline Average co-directorships & $\begin{array}{c}0.028 \\
(0.496)\end{array}$ & $\begin{array}{c}6.097^{* * *} \\
(0.356)\end{array}$ & $\begin{array}{c}-2.540 \\
(1.613)\end{array}$ & $\begin{array}{c}-1.354 \\
(0.951)\end{array}$ & $\begin{array}{l}-1.185 \\
(1.046)\end{array}$ \\
\hline Proportion Non-Executive & $\begin{array}{c}-0.715 \\
(0.694)\end{array}$ & $\begin{array}{c}2.765^{* * *} \\
(0.639)\end{array}$ & $\begin{array}{c}-1.660 \\
(1.088)\end{array}$ & $\begin{array}{c}-0.815 \\
(0.552)\end{array}$ & $\begin{array}{c}-0.844 \\
(0.770)\end{array}$ \\
\hline Tobin's Q & $\begin{array}{c}0.005 \\
(0.003)\end{array}$ & $\begin{array}{c}0.005 \\
(0.005)\end{array}$ & $\begin{array}{c}0.002 \\
(0.004)\end{array}$ & $\begin{array}{c}0.002 \\
(0.003)\end{array}$ & $\begin{array}{c}0.001 \\
(0.001)\end{array}$ \\
\hline Log Assets & $\begin{array}{c}0.352^{* * *} \\
(0.106)\end{array}$ & $\begin{array}{c}0.449^{* * *} \\
(0.105)\end{array}$ & $\begin{array}{c}0.157 \\
(0.121)\end{array}$ & $\begin{array}{c}0.110 \\
(0.089)\end{array}$ & $\begin{array}{c}0.048 \\
(0.051)\end{array}$ \\
\hline Log Exports/Sales & $\begin{array}{c}1.122 \\
(0.684)\end{array}$ & $\begin{array}{c}0.536 \\
(0.391)\end{array}$ & $\begin{array}{c}0.874 \\
(0.590)\end{array}$ & $\begin{array}{c}0.692 \\
(0.448)\end{array}$ & $\begin{array}{c}0.182 \\
(0.184)\end{array}$ \\
\hline Aggr. Industry Patents & $\begin{array}{l}39.681^{* *} \\
(15.425)\end{array}$ & $\begin{array}{c}-0.705 \\
(3.734)\end{array}$ & $\begin{array}{c}39.975^{* * *} \\
(15.480)\end{array}$ & $\begin{array}{c}33.402^{* * *} \\
(12.410)\end{array}$ & $\begin{array}{c}6.572 \\
(4.561)\end{array}$ \\
\hline Aggr. Business Group Patents & $\begin{array}{c}24.353^{* * *} \\
(7.427)\end{array}$ & $\begin{array}{c}-0.593 \\
(0.897)\end{array}$ & $\begin{array}{c}24.524^{* * *} \\
(7.432)\end{array}$ & $\begin{array}{c}16.501^{* * *} \\
(6.174)\end{array}$ & $\begin{array}{l}8.023^{* *} \\
(3.840)\end{array}$ \\
\hline Time Fixed Effects & Yes & $\begin{array}{l}\text { Yes } \\
46\end{array}$ & Yes & Yes & Yes \\
\hline Firm Fixed Effects & Yes & Yes & Yes & Yes & Yes \\
\hline Observations & 11,358 & 11,358 & 11,358 & 11,358 & 11,358 \\
\hline First-Stage F & & & 32.55 & 32.55 & 32.55 \\
\hline
\end{tabular}




\section{Table 5: Network Size Effects: Patent counts}

This table reports results on the effect of network size on firm patents. The sample consists of 11,358 firmyear observations from 2000 to 2007 . Column (1) reports results from an OLS regression; the dependent variable for this model is the total number of patents (international and domestic). Column (2) reports the first stage of the IV regression where the dependent variable is total network size. Column (3) reports the corresponding second stage; the dependent variable for this model is the total number of patents (international and domestic). Columns (4) and (5) report IV second stage results for different types of patents: patents filed domestically (Column (4)) and patents filed internationally (Column (5)). All control variables are lagged by one year and include the following: Network Size measures the number of direct links i.e. the number of other firms with whom a given firm shares common directors; Average co-directorships measures how 'busy' firm's board is, i.e, the average number of firms on whose boards each director of the firm serves; Proportion NonExecutives is the proportion of non-executive directors on the board; Tobin's $Q$ is proxied by the M/B ratio; Total assets in logs is total book value of assets; Log Exports/Sales is total exports of the company divided by its total sales; Aggr. Industry Patents is the aggregate patents count normalized by R\&D expenditure within each industry; Aggr. Business Group Patents is the aggregate patents count normalized by R\&D expenditure within each business group. Standard errors clustered by firm are reported in parentheses. * indicates significance at $10 \% ; * *$ at $5 \% ; * * *$ at $1 \%$.

\begin{tabular}{|c|c|c|c|c|}
\hline & OLS & IV $1^{\text {st }}$ stage & IV $2^{\text {nd }}$ stage & \\
\hline Dep Var: & Patent Count & Network Size & Patent Count & Int. Patent \\
\hline
\end{tabular}

\section{(1)}

$0.013^{* *}$

(0.006)

Network Size

Reform $\times$ Below Threshold

Board size

Average co-directorships

Proportion Non-Executive

Tobin's Q

Log Assets

Log Exports/Sales

Aggr. Industry Patents

Aggr. Business Group Patents

$8.019^{* * *}$

(3.076)

(2)

(3)

(4)

(5)

0.092

(0.068)

0.050

(0.049)

$0.042^{*}$

$(0.022)$

\begin{tabular}{|c|c|c|c|c|c|}
\hline Reform $\times$ Below Threshold & & $\begin{array}{c}-2.101^{* * *} \\
(0.454)\end{array}$ & & & \\
\hline Board size & $\begin{array}{c}-0.002 \\
(0.015)\end{array}$ & $\begin{array}{c}0.435^{* * *} \\
(0.053)\end{array}$ & $\begin{array}{c}-0.037 \\
(0.035)\end{array}$ & $\begin{array}{c}-0.018 \\
(0.025)\end{array}$ & $\begin{array}{l}-0.019 \\
(0.012)\end{array}$ \\
\hline Average co-directorships & $\begin{array}{c}0.068 \\
(0.085)\end{array}$ & $\begin{array}{c}6.097^{* * *} \\
(0.356)\end{array}$ & $\begin{array}{l}-0.419 \\
(0.409)\end{array}$ & $\begin{array}{c}-0.168 \\
(0.323)\end{array}$ & $\begin{array}{l}-0.251^{*} \\
(0.132)\end{array}$ \\
\hline Proportion Non-Executive & $\begin{array}{c}-0.109 \\
(0.173)\end{array}$ & $\begin{array}{c}2.765^{* * *} \\
(0.639)\end{array}$ & $\begin{array}{c}-0.288 \\
(0.237)\end{array}$ & $\begin{array}{c}-0.203 \\
(0.193)\end{array}$ & $\begin{array}{c}-0.085 \\
(0.069)\end{array}$ \\
\hline Tobin's Q & $\begin{array}{c}0.001 \\
(0.001)\end{array}$ & $\begin{array}{c}0.005 \\
(0.005)\end{array}$ & $\begin{array}{c}0.000 \\
(0.001)\end{array}$ & $\begin{array}{l}-0.000 \\
(0.001)\end{array}$ & $\begin{array}{c}0.000 \\
(0.000)\end{array}$ \\
\hline Log Assets & $\begin{array}{l}0.050^{*} \\
(0.030)\end{array}$ & $\begin{array}{c}0.449^{* * *} \\
(0.105)\end{array}$ & $\begin{array}{c}0.013 \\
(0.039)\end{array}$ & $\begin{array}{c}0.007 \\
(0.036)\end{array}$ & $\begin{array}{c}0.006 \\
(0.012)\end{array}$ \\
\hline Log Exports/Sales & $\begin{array}{c}0.241 \\
(0.167)\end{array}$ & $\begin{array}{c}0.536 \\
(0.391)\end{array}$ & $\begin{array}{c}0.194 \\
(0.141)\end{array}$ & $\begin{array}{c}0.144 \\
(0.109)\end{array}$ & $\begin{array}{c}0.051 \\
(0.046)\end{array}$ \\
\hline Aggr. Industry Patents & $\begin{array}{l}8.591^{*} \\
(4.467)\end{array}$ & $\begin{array}{l}-0.705 \\
(3.734)\end{array}$ & $\begin{array}{c}8.647^{*} \\
(4.487)\end{array}$ & $\begin{array}{c}5.675 \\
(4.068)\end{array}$ & $\begin{array}{l}2.972^{* *} \\
(1.168)\end{array}$ \\
\hline Aggr. Business Group Patents & $\begin{array}{l}8.019^{* * *} \\
(3.076)\end{array}$ & $\begin{array}{c}-0.593 \\
(0.897)\end{array}$ & $\begin{array}{l}8.052^{* * *} \\
(3.029)\end{array}$ & $\begin{array}{l}6.310^{* *} \\
(2.845)\end{array}$ & $\begin{array}{l}1.742^{* * *} \\
(0.527)\end{array}$ \\
\hline Time Fixed Effects & Yes & Yes & Yes & Yes & Yes \\
\hline Firm Fixed Effects & Yes & Yes & Yes & Yes & Yes \\
\hline $\begin{array}{l}\text { Observations } \\
\text { First-Stage F }\end{array}$ & 11,358 & $\mathbb{A 7}, 358$ & $\begin{array}{c}11,358 \\
32.55\end{array}$ & $\begin{array}{c}11,358 \\
32.55\end{array}$ & $\begin{array}{c}11,358 \\
32.55\end{array}$ \\
\hline
\end{tabular}


Table 6: Network size effects by types of networks

This table reports results on the effect of network size, differentiated by those arising from executives vs. nonexecutives, on firm patents and current R\&D. The sample consists of 11,358 firm-year observations from 2000 to 2007. All columns report the second stage of an IV regression; the dependent variable for Columns (1) and (2) is current R\&D and for Columns (4) and (5) is international patents. All control variables are lagged by one year and include the following: Network Size measures the number of direct links i.e. the number of other firms with whom a given firm shares common directors; Average co-directorships measures how 'busy' firm's board is, i.e, the average number of firms on whose boards each director of the firm serves; Tobin's Q is proxied by the M/B ratio; Total assets in logs is total book value of assets; Log Exports/Sales is total exports of the company divided by its total sales; Aggr. Industry Patents is the aggregate patents count normalized by R\&D expenditure within each industry; Aggr. Business Group Patents is the aggregate patents count normalized by R\&D expenditure within each business group. Standard errors clustered by firm are reported in parentheses. $*$ indicates significance at $10 \% ; * *$ at $5 \% ; * * *$ at $1 \%$.

\begin{tabular}{|c|c|c|c|c|}
\hline \multirow[t]{2}{*}{ Dep Var: } & \multicolumn{2}{|c|}{ Current R\&D } & \multicolumn{2}{|c|}{ Int. Patents } \\
\hline & Exec. Interlock & Non-Exec. Interlock & Exec. Interlock & Non-Exec. Interlock \\
\hline Network Size, Executive & $\begin{array}{c}0.543^{*} \\
(0.286)\end{array}$ & & $\begin{array}{c}1.173 \\
(0.739)\end{array}$ & \\
\hline Network Size, Non-Executive & & $\begin{array}{l}0.412^{* *} \\
(0.191)\end{array}$ & & $\begin{array}{c}0.891^{*} \\
(0.516)\end{array}$ \\
\hline Average co-directorships & $\begin{array}{c}0.035 \\
(0.024)\end{array}$ & $\begin{array}{c}0.032 \\
(0.022)\end{array}$ & $\begin{array}{c}0.047 \\
(0.047)\end{array}$ & $\begin{array}{c}0.038 \\
(0.043)\end{array}$ \\
\hline Board size & $\begin{array}{c}0.004 \\
(0.003)\end{array}$ & $\begin{array}{c}0.001 \\
(0.003)\end{array}$ & $\begin{array}{c}0.000 \\
(0.006)\end{array}$ & $\begin{array}{c}-0.006 \\
(0.008)\end{array}$ \\
\hline Tobin's Q & $\begin{array}{l}0.000^{* *} \\
(0.000)\end{array}$ & $\begin{array}{l}0.000^{* *} \\
(0.000)\end{array}$ & $\begin{array}{c}0.001 \\
(0.001)\end{array}$ & $\begin{array}{c}0.001 \\
(0.000)\end{array}$ \\
\hline Log Assets & $\begin{array}{c}0.020^{* * *} \\
(0.007)\end{array}$ & $\begin{array}{l}0.013^{*} \\
(0.007)\end{array}$ & $\begin{array}{l}0.029^{* *} \\
(0.014)\end{array}$ & $\begin{array}{c}0.015 \\
(0.012)\end{array}$ \\
\hline Aggr. Industry Patents & $\begin{array}{c}0.908^{* * *} \\
(0.306)\end{array}$ & $\begin{array}{c}0.986^{* * *} \\
(0.279)\end{array}$ & $\begin{array}{l}2.493^{* *} \\
(1.142)\end{array}$ & $\begin{array}{l}2.660^{* *} \\
(1.148)\end{array}$ \\
\hline Aggr. Business Group Patents & $\begin{array}{c}0.608^{* * *} \\
(0.128)\end{array}$ & $\begin{array}{c}0.533^{* * *} \\
(0.107)\end{array}$ & $\begin{array}{c}2.070^{* * *} \\
(0.554)\end{array}$ & $\begin{array}{c}1.909^{* * *} \\
(0.548)\end{array}$ \\
\hline Observations & 11,358 & 11,358 & 11,358 & 11,358 \\
\hline First stage F-stat & 7.98 & 10.13 & 7.98 & 10.13 \\
\hline
\end{tabular}




\section{Table 7: Network Size Effects: Regression Discontinuity Design}

This table reports results on the effect of network size on research and development expenditure and patent filings. The sample consists of 13,773 and 3,030 firm-year observations from 2000 to 2007 in Panel A and B respectively. The first panel (Panel A) reports results from the pooled regression discontinuity (RD) specification (Equation 4) for the entire sample of firms while the second panel (Panel B) reports results for a subsample of firms within a narrowly defined bandwidth (firms whose proportion of non-executives lies between 0.35 and 0.65). All columns of both panels report results from the RD specification with flexible polynomials of the two thresholds i.e. proportion of non-executives, net-worth of firms and their interactions. We condition on time fixed effects and use as instruments the treatment variables as defined by the thresholds: being below the required proportion of non-executives, being eligible for the reform based on net-worth, and their interaction. The dependent variable for the columns are: total research and development expenditure (Column (1)), total current research and development expenditure (Column (2)), total capital research and development expenditure (Column (3)), total number of patents (Column (4)), patents filed domestically (Column (5)) and patents filed internationally (Column (6)). All columns with Tobit specifications report marginal effects. Standard errors clustered by firm are reported in parentheses. * indicates significance at $10 \%$; ** at 5\%; *** at $1 \%$.

\section{PANEL A: Full Sample}

\begin{tabular}{|c|c|c|c|c|c|c|}
\hline & \multicolumn{6}{|c|}{ Dependent Variable: } \\
\hline & $\begin{array}{c}\text { R\&D } \\
\text { (Tobit) }\end{array}$ & $\begin{array}{l}\text { Current R\&D } \\
\text { (Tobit) }\end{array}$ & $\begin{array}{l}\text { Capital R\&D } \\
\text { (Tobit) }\end{array}$ & Patent Count & India Patent & Int. Pat \\
\hline & (1) & (2) & (3) & (4) & (5) & (6) \\
\hline Network Size & $\begin{array}{c}1.703 * * * \\
(0.444)\end{array}$ & $\begin{array}{c}1.184 * * * \\
(0.347)\end{array}$ & $\begin{array}{c}1.013 * * * \\
(0.365)\end{array}$ & $\begin{array}{l}0.084 * * \\
(0.042)\end{array}$ & $\begin{array}{l}0.053 * \\
(0.029)\end{array}$ & $\begin{array}{l}0.031 * * \\
(0.016)\end{array}$ \\
\hline \multicolumn{7}{|l|}{ Polynomials of: } \\
\hline Net Worth (Eligibility) & Yes & Yes & Yes & Yes & Yes & Yes \\
\hline Prop. NE (Requirement) & Yes & Yes & Yes & Yes & Yes & Yes \\
\hline Eligibility $\times$ Requirement & Yes & Yes & Yes & Yes & Yes & Yes \\
\hline Observations & 13,773 & 13,773 & 13,773 & 13,773 & 13,773 & 13,773 \\
\hline First-Stage F & 24.577 & 24.577 & 24.577 & 24.577 & 24.577 & 24.577 \\
\hline
\end{tabular}

PANEL B: Narrow Bandwidth

Dependent Variable:

\begin{tabular}{|c|c|c|c|c|c|}
\hline $\begin{array}{l}\mathrm{R} \& \mathrm{D} \\
\text { (Tobit) }\end{array}$ & $\begin{array}{c}\text { Current R\&D } \\
\text { (Tobit) }\end{array}$ & $\begin{array}{c}\text { Capital R\&D } \\
\text { (Tobit) }\end{array}$ & Patent Count & India Patent & Int. Pat \\
\hline
\end{tabular}

(4)

Network Size

$1.350 * * \quad 1.045 * * *$

Polynomials of:

\begin{tabular}{lcccccc} 
Net Worth (Eligibility) & Yes & Yes & Yes & Yes & Yes & Yes \\
Prop. NE (Requirement) & Yes & Yes & Yes & Yes & Yes & Yes \\
Eligibility $\times$ Requirement & Yes & Yes & Yes & Yes & Yes & Yes \\
\hline Observations & 3,030 & 3,030 & 3,030 & 3,030 & 3,030 & 3,030 \\
First-Stage F & 11.901 & 11.901 & 11.901 & 11.901 & 11.901 & 11.901 \\
\hline \hline
\end{tabular}




\section{Table 8: Network Size Effects: Difference-In-Differences on Above Threshold Firms}

This table reports results on the effect of network size on firm research and development expenditure and on firm patents. The dependent variables for each column are: total R\&D (Column (1)); current R\&D (Column (2)); capital R\&D (Column (3)); total patents filed (Column (4)); patents filed domestically (Column (5)); patents filed internationally (Column (6)). The sample consists of 1,574 firmyear observations consisting of firms that were above-threshold (not required to comply with the reform) and did not hire or fire directors during a period of three years after the reform was implemented. All columns in the table reports results from an difference-in-differences specification comparing treatment and control firms. Treatment firms are defined as firms who increased their network size through an existing director; Control firms are defined as firms who saw no change to their network size. Post-Reform is an indicator for the three year period following the implementation of the reform; it is included as a control in all the specifications. All columns with Tobit specifications report marginal effects. Standard errors in all specifications are clustered by firm and reported in parentheses. * indicates significance at $10 \% ; * *$ at $5 \% ; * * *$ at $1 \%$.

\begin{tabular}{lcccccc}
\hline \hline & \multicolumn{7}{c}{ Dependent Variable: } \\
\cline { 2 - 7 } & $\begin{array}{c}\text { R\&D } \\
\text { (Tobit) }\end{array}$ & $\begin{array}{c}\text { Current R\&D } \\
\text { (Tobit) }\end{array}$ & $\begin{array}{c}\text { Capital R\&D } \\
\text { (Tobit) }\end{array}$ & Patent Count & India Patent & Int. Patent \\
& $(1)$ & $(2)$ & $(3)$ & $(4)$ & $(5)$ & $(6)$ \\
\hline Treatment $\times$ Reform & $0.839^{* * *}$ & $0.307^{* * * *}$ & $-0.192^{* * * *}$ & 0.131 & 0.067 & $0.064^{* *}$ \\
& $(0.056)$ & $(0.042)$ & $(0.036)$ & $(0.110)$ & $(0.080)$ & $(0.034)$ \\
Tobin's Q & -0.011 & $-0.090^{* * *}$ & $0.511^{* * *}$ & -0.015 & -0.008 & -0.007 \\
Time Fixed Effects & $(0.025)$ & $(0.018)$ & $(0.012)$ & $(0.012)$ & $(0.007)$ & $(0.006)$ \\
Firm Fixed Effects & Yes & Yes & Yes & Yes & Yes & Yes \\
& Yes & Yes & Yes & Yes & Yes & Yes \\
\hline \multirow{2}{*}{ Observations } & 1,574 & 1,574 & 1,574 & 1,574 & 1,574 & 1,574 \\
\hline \hline
\end{tabular}




\section{Table 9: Peer Effects: R\&D and Patents}

The tables report results on peer effects in patenting and R\&D from board interlocking networks size. The sample consists of 1,574 firm-year observations consisting of firms that were above-threshold (not required to comply with the reform) and did not hire or fire directors during a period of three years after the reform was implemented. Column (1) reports the second stage of the IV regression from a 2SLS (2 Stage Least Squares) specification, where the dependent variable is the average R\&D expenditure of networked/peer firms. Columns (2) and (3) report 2SLS, IV second stage results for different components of research and development expenditure: current R\&D (Column (2)) and capital R\&D (Column (3)). Column (4), (5) and (6) reports the second stage of the IV regression where the dependent variable is the total number of patents (international and domestic), domestic patents and international patents respectively. The regression includes controls for Tobin's Q, firm and year fixed effects. Standard errors in all specifications are clustered by firm and reported in parentheses. * indicates significance at $10 \%$; ** at $5 \% ; * * *$ at $1 \%$.

\section{PANEL A: First-Stage}

\begin{tabular}{|c|c|c|c|c|c|c|}
\hline & Avg. Network R\&D & Avg. Network Current R\&D & Avg. Network Capital R\&D & Avg. Network Patent Count & Avg. Network India Patent & Avg. Network Int. Patent \\
\hline Treatment $\times$ Reform & $\begin{array}{l}1.603^{* * *} \\
(0.624)\end{array}$ & $\begin{array}{c}0.622^{* * *} \\
(0.175)\end{array}$ & $\begin{array}{l}0.982^{*} \\
(0.540)\end{array}$ & $\begin{array}{c}0.248^{* * * *} \\
(0.074)\end{array}$ & $\begin{array}{l}0.065^{* *} \\
(0.027)\end{array}$ & $\begin{array}{c}0.183^{* * *} \\
(0.054)\end{array}$ \\
\hline
\end{tabular}

PANEL B: Second-Stage

\begin{tabular}{|c|c|c|c|c|c|c|}
\hline & R\&D & Current R\&D & Capital R\&D & Patent Count & India Patent & Int. Patent \\
\hline & (1) & (2) & (3) & (4) & $(5)$ & (6) \\
\hline Avg. Network R\&D & $\begin{array}{l}0.193 * * \\
(0.078)\end{array}$ & & & & & \\
\hline Avg. Network Current R\&D & & $\begin{array}{c}0.387 * * * \\
(0.132)\end{array}$ & & & & \\
\hline Avg. Network Capital R\&D & & & $\begin{array}{c}0.070 \\
(0.046)\end{array}$ & & & \\
\hline Avg. Network Patents & & & & $\begin{array}{l}0.528^{*} \\
(0.301)\end{array}$ & & \\
\hline Avg. Network India Patents & & & & & $\begin{array}{c}0.368 \\
(0.304)\end{array}$ & \\
\hline Avg. Network Intl. Patents & & & & & & $\begin{array}{l}0.982^{* *} \\
(0.488)\end{array}$ \\
\hline Time Fixed Effects & Yes & Yes & Yes & Yes & Yes & Yes \\
\hline Firm Fixed Effects & Yes & Yes & Yes & Yes & Yes & Yes \\
\hline Observations & 1,574 & 1,574 & 1,574 & 1,574 & 1,574 & 1,574 \\
\hline First-Stage F & 11.32 & 16.86 & 6.74 & 14.52 & 10.46 & 11.34 \\
\hline
\end{tabular}




\section{Table 10: Peer Effects weighted by Technological Proximity: R\&D and Patents}

The tables report results on peer effects in patenting and R\&D from board interlocking networks size. The networks are weighted by the intensity of firms' technological proximity using the Jaffe (1986) measure. The sample consists of 1,574 firm-year observations consisting of firms that were above-threshold (not required to comply with the reform) and did not hire or fire directors during a period of three years after the reform was implemented. Column (1) reports the second stage of the IV regression from a 2SLS (2 Stage Least Squares) specification, where the dependent variable is the average R\&D expenditure of networked/peer firms. Columns (2) and (3) report 2SLS, IV second stage results for different components of research and development expenditure: current R\&D (Column (2)) and capital R\&D (Column (3)). Column (4), (5) and (6) reports the second stage of the IV regression where the dependent variable is the total number of patents (international and domestic), domestic patents and international patents respectively. The regression includes controls for Tobin's $\mathrm{Q}$, firm and year fixed effects. Standard errors in all specifications are clustered by firm and reported in parentheses. * indicates significance at 10\%; $* *$ at $5 \%$; $* * *$ at $1 \%$.

PANEL A: First-Stage

\begin{tabular}{|c|c|c|c|c|c|c|}
\hline & Avg. W-Network R\&D & Avg. W-Network Current R\&D & Avg. W-Network Capital R\&D & Avg. W-Network Patent Count & Avg. W-Network India Patent & Avg. W-Network Int. Patent \\
\hline Treatment $\times$ Reform & $\begin{array}{l}0.577^{*} \\
(0.343)\end{array}$ & $\begin{array}{l}0.198^{* *} \\
(0.091)\end{array}$ & $\begin{array}{c}0.379 \\
(0.257)\end{array}$ & $\begin{array}{c}0.056^{\text {**** }} \\
(0.019)\end{array}$ & $\begin{array}{c}0.011^{* * *} \\
(0.003)\end{array}$ & $\begin{array}{l}0.045^{* *} \\
(0.018)\end{array}$ \\
\hline
\end{tabular}

PANEL B: Second-Stage

\begin{tabular}{|c|c|c|c|c|c|c|}
\hline & 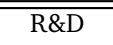 & Current R\&D & Capital R\&D & Patent Count & India Patent & Int. Patent \\
\hline & $(1)$ & (2) & (3) & (4) & (5) & (6) \\
\hline Average Network R\&D & $\begin{array}{c}0.535 \\
(0.349)\end{array}$ & & & & & \\
\hline Average Network Current R\&D & & $\begin{array}{l}1.215^{*} \\
(0.637)\end{array}$ & & & & \\
\hline Average Network Capital R\&D & & & $\begin{array}{c}0.181 \\
(0.156)\end{array}$ & & & \\
\hline Average Network Patents & & & & $\begin{array}{l}2.353^{*} \\
(1.422)\end{array}$ & & \\
\hline Average Network India Patents & & & & & $\begin{array}{c}1.494 \\
(1.286)\end{array}$ & \\
\hline Average Network Intl. Patents & & & & & & $\begin{array}{l}6.052^{* *} \\
(3.053)\end{array}$ \\
\hline Time Fixed Effects & Yes & Yes & Yes & Yes & Yes & Yes \\
\hline Firm Fixed Effects & Yes & Yes & Yes & Yes & Yes & Yes \\
\hline Observations & 1,574 & 1,574 & 1,574 & 1,574 & 1,574 & 1,574 \\
\hline First-Stage F & 16.88 & 6.35 & 15.64 & 8.00 & 7.27 & 2.38 \\
\hline
\end{tabular}




\section{Table 11: Network Size Effects: Patent Propensity}

This table reports results on the effect of network size on the firm's ratio of total patent counts to R\&D. The sample consists of 11,358 firm-year observations from 2000 to 2007 . Column (1) reports results from an OLS regression; the dependent variable for this model is the ratio of total patent counts to R\&D. Column (2) reports the IV second stage results (the first stage results are similar to Column (2) of Table 4); the dependent variable for this model is the ratio of total patent counts to R\&D. Columns (3) and (4) report IV second stage results for different types of patent ratios: ratio of domestic patents to R\&D (Column (3)) and ratio of international patents to R\&D (Column (4)). All control variables are lagged by one year and include the following: Network Size measures the number of direct links i.e. the number of other firms with whom a given firm shares common directors; Proportion Non-Executives is the proportion of non-executive directors on the board; Tobin's Q is proxied by the M/B ratio; Total assets in logs is total book value of assets; Log Exports/Sales is total exports of the company divided by its total sales; Aggr. Industry Patents is the aggregate patents count normalized by R\&D expenditure within each industry; Aggr. Business Group Patents is the aggregate patents count normalized by R\&D expenditure within each business group. Standard errors clustered by firm are reported in parentheses. * indicates significance at $10 \% ; * *$ at $5 \% ; * * *$ at $1 \%$.

\begin{tabular}{|c|c|c|c|c|}
\hline & \multicolumn{4}{|c|}{ Dependent Variable: } \\
\hline & \multicolumn{2}{|c|}{$\frac{\text { Patent Count }}{\mathrm{R} \& \mathrm{D}}$} & \multirow{3}{*}{$\begin{array}{c}\frac{\text { India Patent Count }}{\text { R\&D }} \\
\text { IV } \\
\text { (3) }\end{array}$} & \multirow{3}{*}{$\begin{array}{c}\frac{\text { Int. Patent Count }}{\mathrm{R} \& \mathrm{D}} \\
\text { IV } \\
\text { (4) }\end{array}$} \\
\hline & OLS & IV & & \\
\hline & (1) & (2) & & \\
\hline Network Size & $\begin{array}{l}0.001 * \\
(0.001)\end{array}$ & $\begin{array}{l}0.007 * \\
(0.004)\end{array}$ & $\begin{array}{c}0.004 \\
(0.003)\end{array}$ & $\begin{array}{l}0.003^{* *} \\
(0.001)\end{array}$ \\
\hline Board size & $\begin{array}{c}-0.000 \\
(0.001)\end{array}$ & $\begin{array}{c}-0.003 \\
(0.002)\end{array}$ & $\begin{array}{c}-0.002 \\
(0.002)\end{array}$ & $\begin{array}{c}-0.001 \\
(0.001)\end{array}$ \\
\hline Proportion Non-Executive & $\begin{array}{l}-0.009 \\
(0.016)\end{array}$ & $\begin{array}{c}-0.022 \\
(0.019)\end{array}$ & $\begin{array}{c}-0.015 \\
(0.016)\end{array}$ & $\begin{array}{c}-0.007 \\
(0.005)\end{array}$ \\
\hline Tobin's Q & $\begin{array}{c}0.000 \\
(0.000)\end{array}$ & $\begin{array}{c}0.000 \\
(0.000)\end{array}$ & $\begin{array}{c}-0.000 \\
(0.000)\end{array}$ & $\begin{array}{c}0.000 \\
(0.000)\end{array}$ \\
\hline Log Assets & $\begin{array}{l}0.005 * * \\
(0.002)\end{array}$ & $\begin{array}{c}0.002 \\
(0.003)\end{array}$ & $\begin{array}{c}0.002 \\
(0.003)\end{array}$ & $\begin{array}{c}0.001 \\
(0.001)\end{array}$ \\
\hline Log Exports/Sales & $\begin{array}{c}0.026 * \\
(0.016)\end{array}$ & $\begin{array}{c}0.022 \\
(0.014)\end{array}$ & $\begin{array}{c}0.016 \\
(0.011)\end{array}$ & $\begin{array}{c}0.006 \\
(0.004)\end{array}$ \\
\hline Aggr. Industry Patents & $\begin{array}{l}0.651 * \\
(0.343)\end{array}$ & $\begin{array}{l}0.646^{*} \\
(0.341)\end{array}$ & $\begin{array}{c}0.405 \\
(0.322)\end{array}$ & $\begin{array}{l}0.240 * * \\
(0.098)\end{array}$ \\
\hline Aggr. Business Group Patents & $\begin{array}{c}0.728 * * * \\
(0.253)\end{array}$ & $\begin{array}{c}0.732 * * * \\
(0.249)\end{array}$ & $\begin{array}{l}0.568 * * \\
(0.236)\end{array}$ & $\begin{array}{c}0.164 * * * \\
(0.049)\end{array}$ \\
\hline Time Fixed Effects & Yes & Yes & Yes & Yes \\
\hline Firm Fixed Effects & Yes & Yes & Yes & Yes \\
\hline Observations & 11,358 & 11,358 & 11,358 & 11,358 \\
\hline First-Stage F & & 23.20 & 23.20 & 23.20 \\
\hline
\end{tabular}




\section{Table 12: Innovation vs. Strategic Effect - Equivalents}

This table reports results on the effect of network size on patent equivalents. The sample consists of 11,358 firm-year observations from 2000 to 2007. Column (1) reports the IV second stage results (the first stage results are similar to Column (2) of Table 4); the dependent variable for this model is the total patent equivalents. Columns (2) and (3) report IV second stage results for different types of patent equivalents: domestic patent equivalents (Column (2)) and international patent equivalents (Column (3)). All control variables are lagged by one year and include the following: Network Size measures the number of direct links i.e. the number of other firms with whom a given firm shares common directors; Proportion Non-Executives is the proportion of non-executive directors on the board; Tobin's Q is proxied by the M/B ratio; Total assets in logs is total book value of assets; Log Exports/Sales is total exports of the company divided by its total sales; Aggr. Industry Patents is the aggregate patents count normalized by R\&D expenditure within each industry; Aggr. Business Group Patents is the aggregate patents count normalized by R\&D expenditure within each business group. Standard errors clustered by firm are reported in parentheses. * indicates significance at $10 \% ; * *$ at $5 \% ; * * *$ at $1 \%$.

\begin{tabular}{|c|c|c|c|}
\hline & \multicolumn{3}{|c|}{ Dependent Variable: } \\
\hline & Total Patents & India Patents & Intl. Patents \\
\hline & (IV) & (IV) & (IV) \\
\hline & (1) & (2) & (3) \\
\hline Network Size & $\begin{array}{c}0.055 \\
(0.041)\end{array}$ & $\begin{array}{c}0.032 \\
(0.035)\end{array}$ & $\begin{array}{l}0.023^{*} \\
(0.012)\end{array}$ \\
\hline Previous Equivalent & $\begin{array}{c}-20.031 \\
(12.798)\end{array}$ & $\begin{array}{l}-12.802 \\
(9.574)\end{array}$ & $\begin{array}{l}-7.229^{*} \\
(3.997)\end{array}$ \\
\hline Previous Equivalent $\times$ Network Size & $\begin{array}{c}0.441 \\
(0.668)\end{array}$ & $\begin{array}{c}0.152 \\
(0.702)\end{array}$ & $\begin{array}{l}0.289^{*} \\
(0.165)\end{array}$ \\
\hline First Stage Residual & $\begin{array}{c}-0.042 \\
(0.040)\end{array}$ & $\begin{array}{c}-0.021 \\
(0.034)\end{array}$ & $\begin{array}{l}-0.022^{*} \\
(0.012)\end{array}$ \\
\hline Time Fixed Effects & Yes & Yes & Yes \\
\hline Firm Fixed Effects & Yes & Yes & Yes \\
\hline Observations & 11,358 & 11,358 & 11,358 \\
\hline First-Stage F & 23.20 & 23.20 & 23.20 \\
\hline
\end{tabular}


Figure 1: Treatment and control sets for difference-in-differences strategy This figure shows the different types of companies in our dataset.

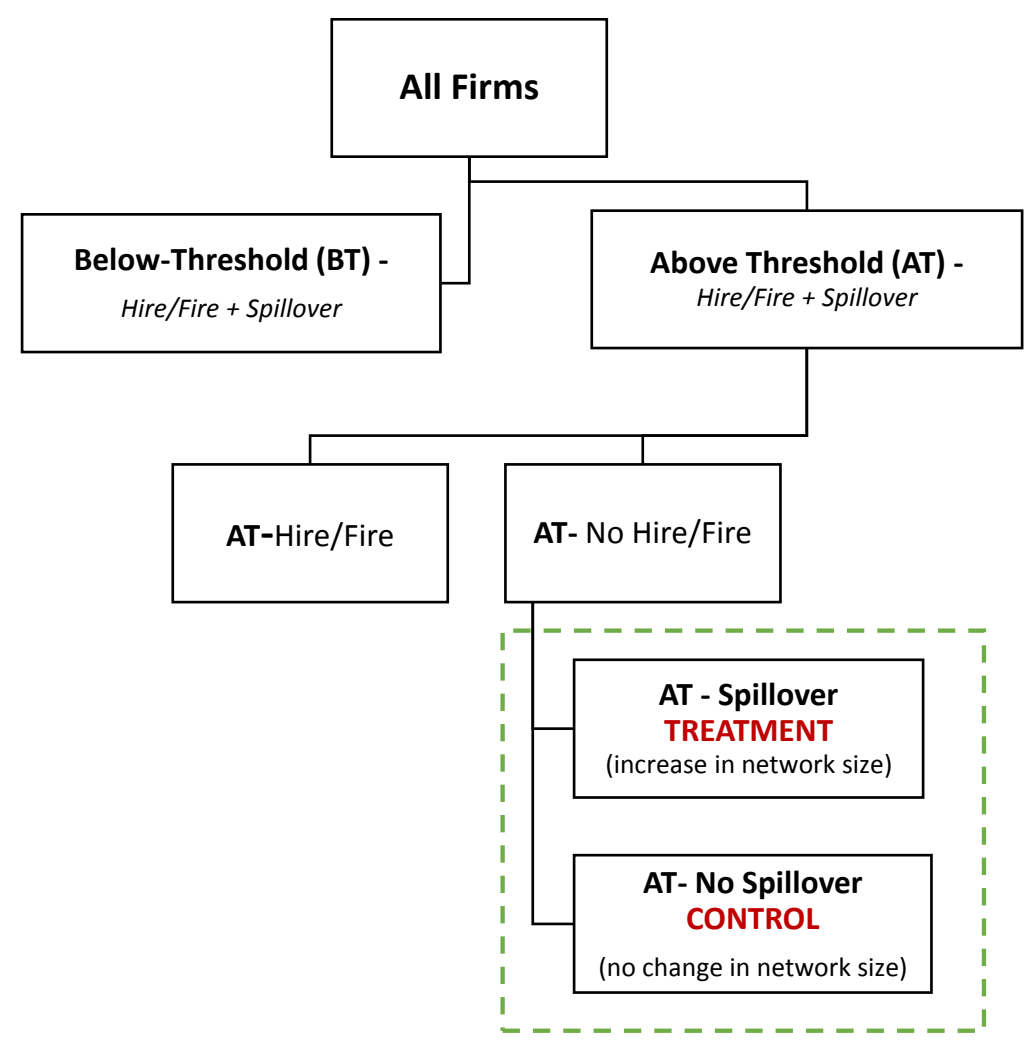


Figure 2: Evolution of outcomes for treatment \& control groups for DiD strategy This figure shows the different types of companies in our dataset.

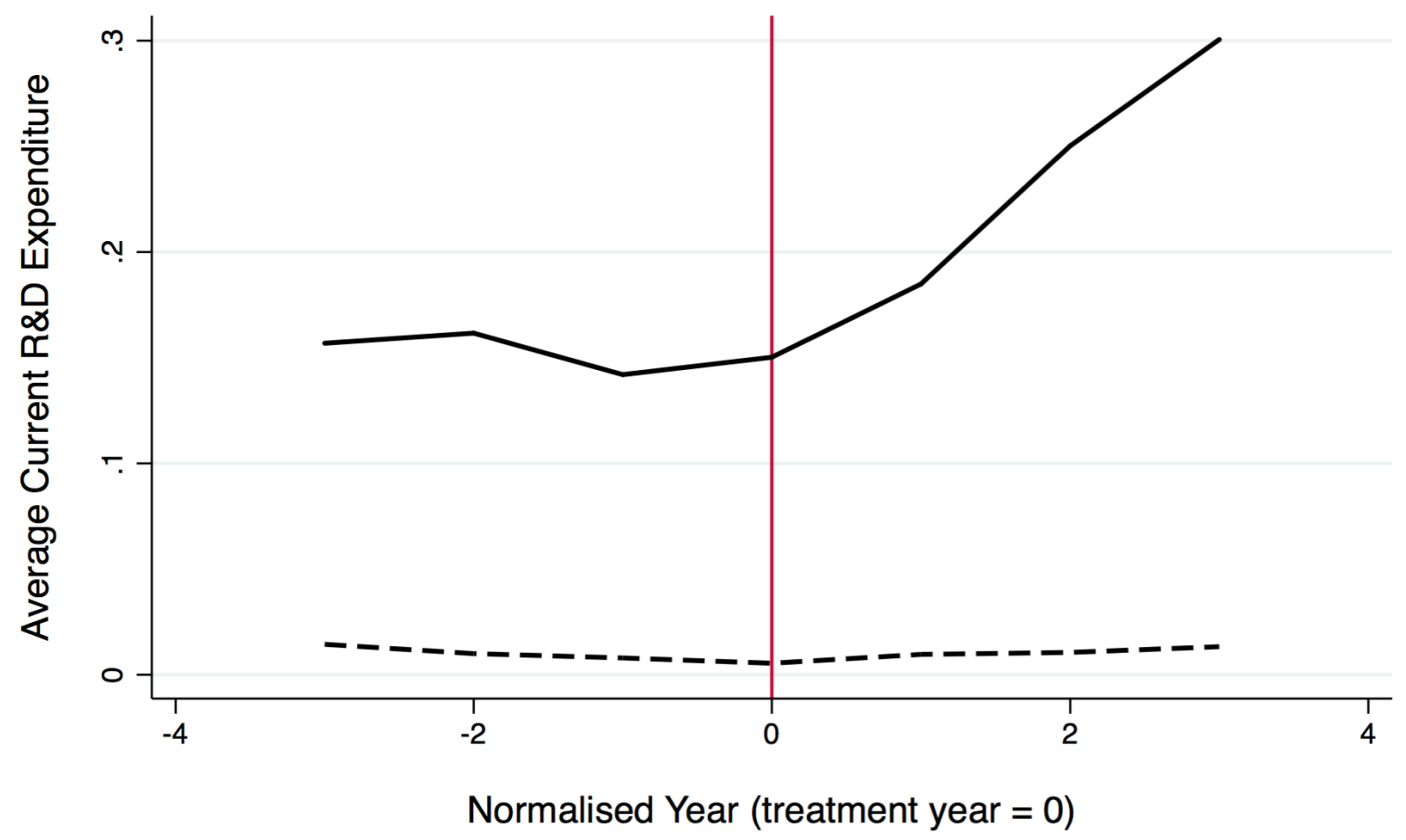

Treatment (Above threshold, spillover \& network size change)

- - - - Control (Above threshold, no spillover) 


\section{ONLINE APPENDIX - NOT FOR PUBLICATION}

\section{A. Corporate Governance Reforms}

India's Companies Act of 1956 sets out board regulations for all registered companies. Listed companies are also subject to Clause 49 issued by the Securities and Exchange Board of India (SEBI). Clause 49 was adopted in 2000 following the recommendation of the Kumaramangalam Birla Committee on corporate governance. The introduction of Clause 49 was motivated mainly by a perceived need to strengthen corporate governance rules in India by introducing mandatory rules (as opposed to the existing non-binding recommendations) in light of recent corporate scandals and the deregulation and opening of the Indian economy. Clause 49 had been preceded by non-binding recommendations laid out in the Confederation of Indian Industry Code for Desirable Corporate Governance in 1998 which had been adopted voluntarily only by few companies.

The focus of Clause 49 was on board independence, board procedures and remuneration, as well as disclosures. The aim was to increase board independence by mandating a minimum share of non-executive and independent directors. Specifically, at least half the board should be comprised of non-executive directors. In case of an executive chairman, at least half the board had to consist of independent directors. In case of a non-executive chairman, at least one third of the board had to consist of independent directors. This latter requirement was further tightened in a revision of Clause 49 in 2008 (which meant that under some conditions even in case of a non-executive chairman, a minimum share of 50 percent of independent directors would be required), but the effect of the revision falls outside of our period of analysis. Clause 49 also imposed a number of other changes which are summarized below (Dharmapala and Khanna, 2013):

- Board composition: Minimum requirement of 50 percent non-executive directors.

- Director Independence: Minimum requirement of 50 percent independent directors if chairman is executive director or 33 percent if chairman is a non-executive.

- Board requirements: Number of boards a director can be on limited to 10 (only 5 chairmanships). A Code of Conduct (Ethics) required.

- Audit Committee: Composed of at least 3 'financially literate' directors (two-thirds must be independent, at least one having accounting or financial management experience); detailed rules and duties of audit committee are specified.

\section{- Disclosures:}

- Related party transactions;

- Accounting treatments and departures;

- Risk management;

- Annual report include discussion of internal controls adequacy, significant trends, risks, and opportunities; 
- Proceeds from offerings;

- Compensation for directors (including non-executives) and obtain shareholders' approval;

- Details of compliance history for last 3 years;

- Corporate governance reports (and disclose adoption, if any, of mandatory and non-mandatory requirements);

- Relevant Information (for example quarterly results, presentations made by companies to analysts etc.) to be made available online.

- Certifications:

- CEO \& CFO: financial statements; effectiveness of internal controls.

- Auditor or company secretary issues compliance with corporate governance.

- Subsidiary Companies:

- At least one Independent director of Holding Company should sit as a director on Board of material non-listed Indian subsidiary.

- Significant transactions report to Holding Company Board.

- Non-binding recommendations:

- Whistleblower policy is optional;

- Independent directors are not longer considered as independent if they have served 9 years or more at company;

- Training board members;

- Evaluate non-executive board performance.

All reform eligible companies were required to submit a quarterly compliance report to the stock exchanges within 15 days from the close of the quarter according to the format shown in Figure A-1. This format includes all provisions as mandated by the reform; compliance status on each item had be verified and signed either by the Compliance Officer or the Chief Executive Officer of the company. 
Figure A-1: Clause 49A Requirements and Compliance Sheet for Companies

This figure shows the official document that all firms listed on the BSE were required to complete as per Clause 49A.

Format of Quarterly Compliance Report on Corporate Governance

Annexure IB

Name of the Company:

Quarter ending on:

\begin{tabular}{|c|c|c|c|}
\hline Particulars & $\begin{array}{c}\text { Clause of } \\
\text { Listing } \\
\text { agreement }\end{array}$ & $\begin{array}{c}\text { Compliance } \\
\text { Status } \\
\text { Yes/No } \\
\end{array}$ & Remarks \\
\hline I. Board of Directors & 491 & & \\
\hline (A)Composition of Board & $49(\mid A)$ & & \\
\hline $\begin{array}{l}\text { (B)Non-executive Directors' compensation \& } \\
\text { disclosures }\end{array}$ & 49 (IB) & & \\
\hline (C)Other provisions as to Board and Committees & 49 (IC) & & \\
\hline (D)Code of Conduct & 49 (ID) & & \\
\hline II. Audit Committee & 49 (II) & & \\
\hline (A)Qualified \& Independent Audit Committee & $49(\| \mathrm{A})$ & & \\
\hline (B)Meeting of Audit Committee & $49(\mathrm{llB})$ & & \\
\hline (C)Powers of Audit Committee & $49(\mathrm{IIC})$ & & \\
\hline (D)Role of Audit Committee & $49 \|(D)$ & & \\
\hline (E)Review of Information by Audit Committee & 49 (IIE) & & \\
\hline III. Subsidiary Companies & 49 (III) & & \\
\hline IV. Disclosures & $49(\mathrm{IV})$ & & \\
\hline (A)Basis of related party transactions & 49 (IV A) & & \\
\hline (B)Board Disclosures & 49 (IV B) & & \\
\hline $\begin{array}{l}\text { (C)Proceeds from public issues, rights issues, } \\
\text { preferential issues etc. }\end{array}$ & $49(\mathrm{~V} \mathrm{C})$ & & \\
\hline (D)Remuneration of Directors & 49 (IV D) & & \\
\hline (E)Management & 49 (IVE) & & \\
\hline (F)Shareholders & 49 (N F) & & \\
\hline V.CEO/CFO Certification & $49(V)$ & & \\
\hline VI. Report on Corporate Governance & 49 (V) & & \\
\hline VII. Compliance & 49 (VII) & & \\
\hline
\end{tabular}

Note:

1) The details under each head shall be provided to incorporate all the information required as per the provisions of the Clause 49 of the Listing Agreement.

2) In the column No.3, compliance or non-compliance may be indicated by $\mathrm{Yes} / \mathrm{No} / \mathrm{N}$.A.. For example, if the Board has been composed in accordance with the Clause 49 I of the Listing Agreement, "Yes" may be indicated. Similarly, in case the company has no related party transactions, the words "N.A." may be indicated against 49 (IV A). 
B. SUPPLEMENTARY TABLES 
Table B1: Summary Statistics by category - before and after the reform where variables are demeaned using industry-level average

This table reports summary statistics of variables used in our regressions for the full sample of firms over the years 2000-2007. We report the mean of each variable after subtracting the industry-level mean, across three groups: (1) company Group A, Group B, and Group C, (2) companies below and above the required threshold introduced by the reform, as well as (3) before and after the reform took effect. Patent data are extracted from USPTO, EPO (PATSTAT version April 2010), EKASWA, iPairs, and BigPatents India. All firm level variables are obtained from the PROWESS database. Only firms listed on the BSE are part of the sample.

\begin{tabular}{|c|c|c|c|c|c|c|}
\hline & \multicolumn{3}{|c|}{ Above required proportion } & \multicolumn{3}{|c|}{ Below required proportion } \\
\hline & $\begin{array}{r}\text { Before reform } \\
\text { Mean }\end{array}$ & $\begin{array}{r}\text { After reform } \\
\text { Mean }\end{array}$ & $\begin{array}{r}\text { Difference } \\
\text { t-statistic }\end{array}$ & $\begin{array}{r}\text { Before reform } \\
\text { Mean }\end{array}$ & $\begin{array}{r}\text { After reform } \\
\text { Mean }\end{array}$ & $\begin{array}{r}\text { Difference } \\
\text { t-statistic }\end{array}$ \\
\hline \multicolumn{7}{|l|}{ Group A } \\
\hline$R \& D$ & 0.189 & 0.354 & -1.999 & 0.160 & 0.234 & -0.739 \\
\hline Current R\&D & 0.158 & 0.319 & -2.096 & 0.151 & 0.205 & -0.611 \\
\hline Capital R\&D & 0.085 & 0.148 & -1.124 & 0.048 & 0.119 & -1.021 \\
\hline Total Patent Count & 0.185 & 0.840 & -1.133 & 0.328 & 1.720 & -0.876 \\
\hline Network Size & 7.092 & 11.054 & -2.719 & 3.524 & 8.378 & -2.690 \\
\hline Assets (log) & 1.835 & 2.300 & -2.862 & 1.656 & 1.974 & -1.399 \\
\hline Tobin's Q & 0.202 & 0.000 & 1.171 & 0.355 & 0.045 & 1.300 \\
\hline Board size & 2.359 & 2.996 & -2.130 & 1.662 & 1.907 & -0.924 \\
\hline \multicolumn{7}{|l|}{ Group B } \\
\hline$R \& D$ & 0.017 & 0.085 & -2.089 & -0.006 & 0.010 & -0.478 \\
\hline Current R\&D & -0.008 & 0.075 & -2.845 & -0.006 & 0.005 & -0.364 \\
\hline Capital R\&D & 0.021 & 0.025 & -0.168 & 0.004 & 0.013 & -0.396 \\
\hline Total Patent Count & 0.161 & -0.093 & 2.059 & -0.040 & -0.063 & 0.226 \\
\hline Network Size & 2.781 & 3.103 & -0.387 & 0.763 & -0.025 & 0.971 \\
\hline Assets (log) & 0.615 & 0.851 & -2.471 & 0.498 & 0.474 & 0.207 \\
\hline Tobin's Q & 0.084 & 0.032 & 0.383 & 0.255 & 0.105 & 0.701 \\
\hline Board size & 0.891 & 1.013 & -0.673 & 0.466 & 0.041 & 2.063 \\
\hline \multicolumn{7}{|l|}{ Group C } \\
\hline$R \& D$ & -0.031 & -0.055 & 1.547 & -0.110 & -0.121 & 1.038 \\
\hline Current R\&D & -0.025 & -0.052 & 1.990 & -0.088 & -0.106 & 2.068 \\
\hline Capital R\&D & -0.017 & -0.026 & 0.974 & -0.046 & -0.047 & 0.163 \\
\hline Total Patent Count & -0.189 & -0.347 & 2.653 & -0.160 & -0.259 & 2.473 \\
\hline Network Size & -0.799 & -1.315 & 1.285 & -3.600 & -4.390 & 2.307 \\
\hline Assets (log) & -0.267 & -0.279 & 0.230 & -0.872 & -0.885 & 0.223 \\
\hline Tobin's Q & 0.031 & 0.201 & -0.402 & 0.048 & -0.181 & 2.604 \\
\hline Board size & 0.020 & 0.001 & 0.187 & -1.452 & -1.085 & -3.505 \\
\hline
\end{tabular}




\section{Table B2: Peer Effects weighted by Technological Proximity (proximity measure \#1): R\&D and Patents}

The tables report results on peer effects in patenting and R\&D from board interlocking networks size. The networks are weighted by the intensity of firms' technological proximity where proximity is measured by a binary variable that is equal to one if two interlocked firms have patented in at least one common IPC category at the 3-digit level. The sample consists of 1,574 firm-year observations consisting of firms that were above-threshold (not required to comply with the reform) and did not hire or fire directors during a period of three years after the reform was implemented. Column (1) reports the second stage of the IV regression from a 2SLS (2 Stage Least Squares) specification, where the dependent variable is the average R\&D expenditure of networked/peer firms. Columns (2) and (3) report 2SLS, IV second stage results for different components of research and development expenditure: current R\&D (Column (2)) and capital R\&D (Column (3)). Column (4), (5) and (6) reports the second stage of the IV regression where the dependent variable is the total number of patents (international and domestic), domestic patents and international patents respectively. The regression includes controls for Tobin's Q, firm and year fixed effects. Standard errors in all specifications are clustered by firm and reported in parentheses. * indicates significance at $10 \% ; * *$ at $5 \% ; * * *$ at $1 \%$.

PANEL A: First-Stage

\begin{tabular}{|c|c|c|c|c|c|c|}
\hline & Avg. W-Network R\&D & Avg. W-Network Current R\&D & Avg. W-Network Capital R\&D & Avg. W-Network Patent Count & Avg. W-Network India Patent & Avg. W-Network Int. Patent \\
\hline Treatment $\times$ Reform & $\begin{array}{c}0.579^{*} \\
(0.343)\end{array}$ & $\begin{array}{l}0.200^{* *} \\
(0.091)\end{array}$ & $\begin{array}{c}0.379 \\
(0.257)\end{array}$ & $\begin{array}{c}0.059^{* * * *} \\
(0.019)\end{array}$ & $\begin{array}{c}0.012^{* * * *} \\
(0.004)\end{array}$ & $\begin{array}{c}0.047^{* * * *} \\
(0.018)\end{array}$ \\
\hline
\end{tabular}

PANEL B: Second-Stage

\begin{tabular}{|c|c|c|c|c|c|c|}
\hline & R\&D & Current R\&D & Capital R\&D & Patent Count & India Patent & Int. Patent \\
\hline & (1) & (2) & (3) & (4) & (5) & (6) \\
\hline Average Weighted Network R\&D & $\begin{array}{c}0.533 \\
(0.347)\end{array}$ & & & & & \\
\hline Average Weighted Network Current R\&D & & $\begin{array}{l}1.200^{*} \\
(0.623)\end{array}$ & & & & \\
\hline Average Weighted Network Capital R\&D & & & $\begin{array}{c}0.181 \\
(0.156)\end{array}$ & & & \\
\hline Average Weighted Network Patents & & & & $\begin{array}{l}2.240^{*} \\
(1.332)\end{array}$ & & \\
\hline Average Weighted Network India Patents & & & & & $\begin{array}{c}1.443 \\
(1.228)\end{array}$ & \\
\hline Average Weighted Network Intl. Patents & & & & & & $\begin{array}{l}5.416^{* *} \\
(2.755)\end{array}$ \\
\hline Time Fixed Effects & Yes & Yes & Yes & Yes & Yes & Yes \\
\hline Firm Fixed Effects & Yes & Yes & Yes & Yes & Yes & Yes \\
\hline Observations & 1,574 & 1,574 & 1,574 & 1,574 & 1,574 & 1,574 \\
\hline First-Stage F & 16.81 & 6.32 & 15.57 & 7.37 & 6.98 & 2.18 \\
\hline
\end{tabular}




\section{Table B3: Peer Effects weighted by Technological Proximity (proximity measure \#2): R\&D and Patents}

The tables report results on peer effects in patenting and R\&D from board interlocking networks size. The networks are weighted by the intensity of firms' technological proximity where proximity is measured as the fraction of 3-digit IPC classes that two interlocked companies have in common. The sample consists of 1,574 firm-year observations consisting of firms that were above-threshold (not required to comply with the reform) and did not hire or fire directors during a period of three years after the reform was implemented. Column (1) reports the second stage of the IV regression from a 2SLS (2 Stage Least Squares) specification, where the dependent variable is the average R\&D expenditure of networked/peer firms. Columns (2) and (3) report 2SLS, IV second stage results for different components of research and development expenditure: current R\&D (Column (2)) and capital R\&D (Column (3)). Column (4), (5) and (6) reports the second stage of the IV regression where the dependent variable is the total number of patents (international and domestic), domestic patents and international patents respectively. The regression includes controls for Tobin's $Q$, firm and year fixed effects. Standard errors in all specifications are clustered by firm and reported in parentheses. * indicates significance at $10 \% ; * *$ at $5 \% ; * * *$ at $1 \%$.

PANEL A: First-Stage

\begin{tabular}{|c|c|c|c|c|c|c|}
\hline & Avg. W-Network R\&D & Avg. W-Network Current R\&D & Avg. W-Network Capital R\&D & Avg. W-Network Patent Count & Avg. W-Network India Patent & Avg. W-Network Int. Patent \\
\hline Treatment $\times$ Reform & $\begin{array}{l}0.572^{*} \\
(0.343)\end{array}$ & $\begin{array}{l}0.193^{* *} \\
(0.090)\end{array}$ & $\begin{array}{c}0.380 \\
(0.257)\end{array}$ & $\begin{array}{c}0.053^{* * *} \\
(0.018)\end{array}$ & $\begin{array}{c}0.009^{* * *} \\
(0.003)\end{array}$ & $\begin{array}{l}0.043^{* *} \\
(0.018)\end{array}$ \\
\hline
\end{tabular}

PANEL B: Second-Stage

\begin{tabular}{|c|c|c|c|c|c|c|}
\hline & R\&D & Current R\&D & Capital R\&D & Patent Count & India Patent & Int. Patent \\
\hline & (1) & (2) & (3) & (4) & (5) & (6) \\
\hline Average Weighted Network R\&D & $\begin{array}{c}0.540 \\
(0.355)\end{array}$ & & & & & \\
\hline Average Weighted Network Current R\&D & & $\begin{array}{l}1.248^{*} \\
(0.667)\end{array}$ & & & & \\
\hline Average Weighted Network Capital R\&D & & & $\begin{array}{c}0.180 \\
(0.156)\end{array}$ & & & \\
\hline Average Weighted Network Patents & & & & $\begin{array}{c}2.475 \\
(1.510)\end{array}$ & & \\
\hline Average Weighted Network India Patents & & & & & $\begin{array}{c}1.552 \\
(1.344)\end{array}$ & \\
\hline Average Weighted Network Intl. Patents & & & & & & $\begin{array}{l}6.711^{* *} \\
(3.395)\end{array}$ \\
\hline Time Fixed Effects & Yes & Yes & Yes & Yes & Yes & Yes \\
\hline Firm Fixed Effects & Yes & Yes & Yes & Yes & Yes & Yes \\
\hline Observations & 1,574 & 1,574 & 1,574 & 1,574 & 1,574 & 1,574 \\
\hline First-Stage F & 16.85 & 6.27 & 15.73 & 8.42 & 7.37 & 2.54 \\
\hline
\end{tabular}


Table B4: Network Size Effects: Foreign patent counts weighted by number of forward citations received

This table reports results on the effect of network size on firm patents where patents have been weighted by the number of forward citations received: (a) within 3 years after publication of a patent ("\# Cites $3 y$ "), (b) within 5 years after publication of a patent ("\# Cites $5 y$ "), and (c) within 10 years after publication of a patent ("\# Cites 10y"). The sample consists of 11,358 firm-year observations from 2000 to 2007. Column (1) reports results from an OLS regression; the dependent variable for this model is citation count (a), i.e. all forward citations received within 3 years after publication of the patent ("\# Cites 3y"). Column (2) reports the first stage of the IV regression where the dependent variable is total network size. Column (3) reports the corresponding second stage; the dependent variable for this model is citation count (a), i.e. all forward citations received within 3 years after publication of the patent ("\# Cites 3y"). Columns (4) and (5) report IV second stage results for dependent variables (b) and (c) respectively. All control variables are lagged by one year and include the following: Network Size measures the number of direct links i.e. the number of other firms with whom a given firm shares common directors; Average co-directorships measures how 'busy' firm's board is, i.e, the average number of firms on whose boards each director of the firm serves; Tobin's $Q$ is proxied by the M/B ratio; Total assets in logs is total book value of assets; Log Exports/Sales is total exports of the company divided by its total sales; Aggr. Industry Patents is the aggregate patents count normalized by R\&D expenditure within each industry; Aggr. Business Group Patents is the aggregate patents count normalized by R\&D expenditure within each business group. Standard errors clustered by firm are reported in parentheses. * indicates significance at $10 \% ; * *$ at $5 \% ; * * *$ at $1 \%$.

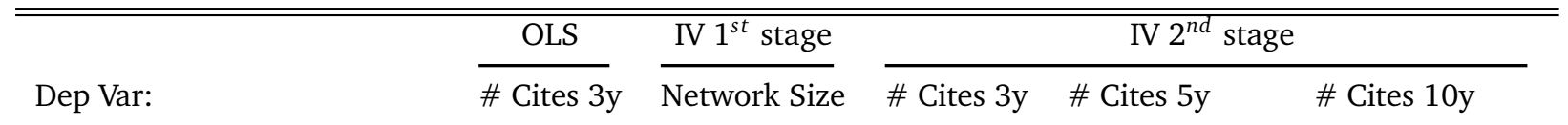

(2)

(3)

(4)

(5)

0.044

(0.058)

(1)

$-0.002$

(0.004)

Network Size

Reform $\times$ Below Threshold

Board size

Average co-directorships

Proportion Non-Executive

Tobin's Q

Log Assets

Log Exports/Sales

Aggr. Industry Patents

Aggr. Business Group Patents

$-0.304$

(0.745)

$4.324^{*}$
0.051

$-2.101^{* * *}$

(0.454)

$0.435^{* * *}$

(0.053)

$-0.013$

(0.020)

$-0.015$

(0.026)

$-0.286$

(0.229)

$-0.353$

(0.299)

$-0.128$

$-0.170$

(0.211)

(0.639)

(0.173)

0.0008

0.001

(0.001)

(0.005)

(0.001)

$0.037^{*}$

(0.021)

(0.017)

0.152

(0.143)

(0.112)

(0.391)

$-0.705$

(3.734)

4.355*

$5.415^{*}$

(3.227)

$-0.593$

(0.897)

$-0.285$

0.177

(1.295)

Yes

Yes

Yes

Firm Fixed Effects

Observations

11,358

11,358

11,358

32.55 


\section{Matching Of Patent Data}

The original PROWESS dataset contains 25,404 unique firm names. After cleaning and standardizing, we have 25,319 unique firm names which are matched with the assignee names of CGPDT, USPTO, and EPO patents. EPO and USPTO patent data come from EPO's PATSTAT database whereas filings with the Indian patent office come from three sources as explained in Section 3.2 in the main text: iPairs, EKASWA, and BigPatents India. The USPTO, and EPO patent files contain 1,431, and 705 unique assignee names of Indian residents respectively. The assignees contain a large range of different assignee types, including private individuals, universities, and research institutes. We attempt to keep only private and state-owned companies because none of the other assignee types is contained in PROWESS. After dropping any assignees that are not private or state-owned companies, cleaning/standardizing assignee names, and keeping only patents applied for between 1990-2008, we obtain 375 and 314 unique names in the USPTO and EPO patent files, respectively. These assignees correspond to 1,489 and 1,717 patent filings respectively. Table C1 shows the resulting matching rates. The Indian patent data was compiled in different ways. EKASWA provided us with the complete set of assignees and patents which we matched to our sample of PROWESS firms. iPairs and BigPatents India provide online access to the data. We downloaded all assignee names from iPairs and matched them to our sample of firms and then downloaded only those patents for the matched iPairs assignee names. When downloading the patent data, we checked that at least one inventor on a given patent document indicates an Indian residence. This increases the likelihood that a given patent was filed by the headquarter/subsidiary in India. We also trawled BigPatents India for companies in our PROWESS dataset and obtained additional patents in this way. Moreover, we cross-checked our USPTO, EPO and Indian patent data using equivalents to ensure that the match is consistent. This implies that if, for example, a matched USPTO patent has an Indian equivalent, we verify that we also matched the Indian equivalent to its owner. 


\section{Table C1: Matched dataset}

This table shows the matching rates between the various patent databases. USPTO and EPO patents are extracted from PATSTAT version April 2010. CGPDT patents are from EKASWA, iPairs, and BigPatents India. The original PROWESS dataset contains 25,404 unique firm names. After cleaning and standardizing, we have 25,319 unique firm names which are matched with the assignee names of CGPDT, USPTO, and EPO patents. The USPTO, and EPO patent files contain 1,431, and 705 unique assignee names of Indian residents respectively. After dropping any assignees that are not private or state-owned companies, cleaning/standardizing assignee names, and keeping only patents applied for between 1990-2008, we obtain 375 and 314 unique names in the USPTO and EPO patent files, respectively. These assignees correspond to 1,489 and 1,717 patent filings respectively.

\begin{tabular}{|c|c|c|c|c|c|c|c|}
\hline & \multicolumn{4}{|c|}{ Assignee names } & \multicolumn{3}{|c|}{ Patents } \\
\hline & $\begin{array}{l}\text { Raw } \\
\text { Data }\end{array}$ & $\begin{array}{c}\text { Cleaned } \\
\text { Data }\end{array}$ & \# Matched & Match Success & \# Patents & \# Matched & Match Success \\
\hline iPairs & 105,731 & 97,540 & 218 & $0.22 \%$ & & 6,851 & \\
\hline BigPatents India & & & 70 & & & 219 & \\
\hline EKASWA & 13,842 & 11,260 & 369 & $3.28 \%$ & 21,595 & 2,769 & $12.82 \%$ \\
\hline CGPDT & & & 506 & & & 9,485 & \\
\hline USPTO & 1,431 & 375 & 173 & $46.13 \%$ & 1,976 & 1,489 & $75.35 \%$ \\
\hline EPO & 705 & 314 & 168 & $53.50 \%$ & 4,110 & 1,717 & $41.78 \%$ \\
\hline
\end{tabular}




\section{Indian Patent System}

This section provides some background information on the Indian patent system, which is relevant for the interpretation of our results. Since India's independence from the British Empire in 1947, the Indian patent system has undergone two sets of radical reforms in opposite directions. The first dramatic change to the patent system was enacted in 1970 with the India Patents Act, which came in force in April 1972. The principal change introduced by the Patents Act was to deny patentability to pharmaceutical and chemical products. While pharmaceutical and chemical process inventions remained patentable, their patent life was restricted to 7 years counting from the filing date whereas the life of any other patent was 14 years. Moreover, only a single process or method was patentable for a specific drug. The 1970 Patent Act also enacted provisions that allowed compulsory licensing of pharmaceutical drug related process patents.

When India entered the World Trade Organization (WTO) in January 1995, it also adopted the Trade-Related Aspects of Intellectual Property Rights (TRIPS) Agreement. Under TRIPS, India was required to fundamentally change its intellectual property system in the opposite direction of what the 1970 Patent Act had achieved. This change was carried out through three major amendments to the 1970 Patents Act. The most significant change required by TRIPS was the recognition of the patentability of pharmaceutical and chemical product patents, although India was allowed to postpone their granting until January 2005. However, according to TRIPS regulations, patentees were allowed to file pharmaceutical and chemical product patent applications during this 10 -year transition period through a so-called 'pipeline' system. While operating since January 1995, the pipeline system was formally enacted only by the 1999 Patents (Amendment) Act. ${ }^{a}$ In 2002, India brought its legal system further inline with TRIPS requirements through the the 2002 Patents (Amendment) Act, which among other things, introduced a 20-year patent validity term and allowed patents to cover multiple processes/methods. In its 2002 Patents (Amendment) Act, India formally recognized its accession in 1998 to the Paris Convention, which stipulates national treatment for foreign assignees and their right to use 'priority' derived from patent filings in other Paris Convention countries within a 12-months period preceding filing in India. It also formally recognized India's accession in 1998 to the Patent Cooperation Treaty (PCT), which allows filing for patent protection through the World Intellectual Property Organization (WIPO). ${ }^{\mathrm{b}}$ Finally, the 2005 Patents (Amendment) Act allowed the granting of pharmaceutical and chemical product patents.

\footnotetext{
${ }^{a}$ Applicants were allowed to file patent applications, but they would not be examined and published until the end of the 10-year transition period. The main advantages of filing for a patent through the pipeline system was that patent examination was executed in order of filing date once the transition period had ended and that prior art was evaluated according to the available information at the priority date of the patent (which could have coincided with the application date). (Mueller, 2006) reports that 8,926 patent applications were filed during the 10-year transition period through the pipeline system.

${ }^{\mathrm{b}}$ This meant applicants could file for patent protection in India by filing a PCT application with WIPO and designating India for the national phase of the filing. Similarly, Indian nationals are able to file patent applications with WIPO and designate India as well as other PCT members for entry into the national phase.
} 


\section{E. TRIPS REFORM}

As discussed in Section D above, the India Patents Act of 1970 prohibited the granting of pharmaceutical and chemical product patents. India's WTO accession in 1995 forced the government to re-align its patent system with TRIPS, which meant among other things an extension of the statutory patent life and the patentability of pharmaceutical and chemical product inventions. While patent applications on pharmaceutical and chemical compounds could be filed beginning January 1995, these applications were only examined and granted from January 2005 onward. Since this falls into our sample period, this section discusses potential implications for our analysis.

Chaudhuri et al. (2006), among others, argue that prohibiting patentability of pharmaceutical and chemical products had a major positive impact on the development of a domestic pharmaceutical industry in India. This suggests that the re-introduction of pharmaceutical product patents could have also impacted the domestic pharmaceutical industry and hence affected R\&D expenditure and patent filings. Arora et al. (2011) find an increase in private returns to $R \& D$ conducted by a sample of publicly traded Indian pharmaceutical companies during the post-WTO accession period. Several other articles (e.g. Kale and Little (2007)) and press reports (Economist June 16 2005; Financial Times April 17 2008) pointed to evidence of the emergence of a "research-driven" Indian pharmaceutical industry following WTO accession. Yet, evidence by Arora et al. (2009) shows that this "researchdriven" Indian pharmaceutical industry still focuses largely on process innovations, where the increase in research activity and patenting observed since 2005 is attributed to an overwhelming extent to increased sales of generics and bulk drugs in Western markets, especially the U.S. This suggests that while there was an increase in R\&D and patent filings post-2005, these patents and R\&D are largely concerned with the same type of research, i.e., processes and production methods as before 2005.

In our setting, a primary concern is that the fundamental change in the Indian patent system for pharmaceutical and chemical product patents that became effective in 2005, induced a common correlated shock specific to pharmaceutical and chemical companies in our sample. Since the corporate governance reform that we exploit to identify the network size effect predates the granting of pharmaceutical and chemical patents, it is reasonable to assume that it is uncorrelated with the change in the patent system. Nevertheless, to investigate the presence of a pharma/chemicals-specific shock, we include in specification (2) an indicator variable that assumes the value one for the pharmaceutical and chemical sector from 2005 onward (Pharma $\times$ TRIPS). This pharma/chemicals-specific trend break captures a potential common correlated effect induced by the granting of pharmaceutical and chemical product patents beginning 2005. Our results shown in Table E1, Column (1), indicate no statistically significant association between the pharma/chemicals shock and network size, as would be expected. The shock is not significant in Column (2) either where we estimate the effect of network size on R\&D. The coefficient on R\&D is still statistically significant and only slightly smaller in magnitude than in Table 4 . When we use patent counts as the dependent variable in Columns (3) to (5), we see that the TRIPS dummy variable is statistically significant only for the specification that uses patent counts abroad as the dependent variable. The indicator variable for the pharma/chemicals-specific trend break has a coefficient of 0.407 in Column (5), implying that the introduction of pharmaceuti- 
cal and chemical product patents increased international patent filings by nearly half units more. The results shown in Column (5) also demonstrate that the magnitude and sign of the coefficient on network size is robust to including the TRIPS dummy variable. 
Table E1: TRIPS Shock

This table reports results on the effect of network size on firm research and development expenditure and patents accounting for the TRIPS agreement. The sample consists of 11,358 firm-year observations from 2000 to 2007 . All specifications in this table control for the effect of the TRIPS reform on patenting. Column (1) reports the first stage of the IV regression where the dependent variable is total network size. Column (2) reports the corresponding second stage; the dependent variable for this model is the total expenditure on R\&D. Columns (3), (4) and (5) report IV second stage results for: total number of patents (Column (3)), patents filed domestically (Column (4)) and patents filed internationally (Column (5)). All control variables are lagged by one year and include the following: Proportion Non-Executive is the proportion of Non-Executive directors in the board; Assets in logs is total book value of assets; Network Size measures the number of direct links i.e. the number of other firms with whom a given firm shares common directors; Aggr. Industry Patents is the aggregate patents count normalized by R\&D expenditure within each industry; Aggr. Business Group Patents is the aggregate patents count normalized by R\&D expenditure within each business group. Bootstrapped standard errors are reported in parentheses. * indicates significance at $10 \%$; ** at $5 \%$; *** at $1 \%$.

Dependent Variable:

\begin{tabular}{ccccc}
\hline $\begin{array}{c}\text { (1) } \\
\begin{array}{c}\text { Network Size } \\
\text { (IV1) }\end{array}\end{array}$ & $\begin{array}{c}(2) \\
\text { R\&D } \\
\text { (IV II) }\end{array}$ & $\begin{array}{c}\text { Patent Count } \\
\text { (IV II) }\end{array}$ & $\begin{array}{c}\text { (4) } \\
\text { India Patent } \\
\text { (IV II) }\end{array}$ & $\begin{array}{c}\text { Int. Paten } \\
\text { (IV II) }\end{array}$ \\
& $\begin{array}{c}0.395^{* *} \\
(0.198)\end{array}$ & 0.075 & 0.043 & 0.032 \\
& $(0.053)$ & $(0.038)$ & $(0.017)$
\end{tabular}

\begin{tabular}{|c|c|c|c|c|c|}
\hline Network Size & & $\begin{array}{l}0.395 * * \\
(0.198)\end{array}$ & $\begin{array}{c}0.075 \\
(0.053)\end{array}$ & $\begin{array}{c}0.043 \\
(0.038)\end{array}$ & $\begin{array}{l}0.032 * \\
(0.017)\end{array}$ \\
\hline Reform $\times$ Below Threshold & $\begin{array}{c}-2.685 * * * * \\
(0.556)\end{array}$ & & & & \\
\hline Pharma $\times$ TRIPS & $\begin{array}{c}1.242 \\
(0.787)\end{array}$ & $\begin{array}{c}2.999 \\
(2.876)\end{array}$ & $\begin{array}{c}1.026 \\
(0.776)\end{array}$ & $\begin{array}{c}0.619 \\
(0.647)\end{array}$ & $\begin{array}{l}0.407 * \\
(0.224)\end{array}$ \\
\hline Board size & $\begin{array}{c}0.436 * * * \\
(0.061)\end{array}$ & $\begin{array}{c}-0.134 \\
(0.094)\end{array}$ & $\begin{array}{c}-0.030 \\
(0.029)\end{array}$ & $\begin{array}{c}-0.015 \\
(0.021)\end{array}$ & $\begin{array}{c}-0.015 \\
(0.011)\end{array}$ \\
\hline Proportion Non-Executive & $\begin{array}{c}2.921 * * * \\
(0.762)\end{array}$ & $\begin{array}{c}-1.406 \\
(0.962)\end{array}$ & $\begin{array}{c}-0.238 \\
(0.212)\end{array}$ & $\begin{array}{c}-0.180 \\
(0.176)\end{array}$ & $\begin{array}{c}-0.058 \\
(0.061)\end{array}$ \\
\hline Tobin's Q & $\begin{array}{c}0.003 \\
(0.005)\end{array}$ & $\begin{array}{c}0.003 \\
(0.003)\end{array}$ & $\begin{array}{c}0.000 \\
(0.001)\end{array}$ & $\begin{array}{c}0.000 \\
(0.001)\end{array}$ & $\begin{array}{c}0.000 \\
(0.000)\end{array}$ \\
\hline Log Assets & $\begin{array}{c}0.545^{* * * *} \\
(0.130)\end{array}$ & $\begin{array}{c}0.177 \\
(0.116)\end{array}$ & $\begin{array}{c}0.018 \\
(0.037)\end{array}$ & $\begin{array}{c}0.010 \\
(0.034)\end{array}$ & $\begin{array}{c}0.008 \\
(0.011)\end{array}$ \\
\hline Log Exports/Sales & $\begin{array}{c}0.686 \\
(0.493)\end{array}$ & $\begin{array}{c}0.890 \\
(0.592)\end{array}$ & $\begin{array}{c}0.200 \\
(0.141)\end{array}$ & $\begin{array}{c}0.147 \\
(0.110)\end{array}$ & $\begin{array}{c}0.053 \\
(0.046)\end{array}$ \\
\hline Aggr. Industry Patents & $\begin{array}{l}-6.345 \\
(5.638)\end{array}$ & $\begin{array}{c}21.812^{* *} \\
(9.017)\end{array}$ & $\begin{array}{c}2.540 \\
(4.138)\end{array}$ & $\begin{array}{c}2.011 \\
(4.279)\end{array}$ & $\begin{array}{c}0.529 \\
(1.456)\end{array}$ \\
\hline Aggr. Business Group Patents & $\begin{array}{c}-0.938 \\
(1.004)\end{array}$ & $\begin{array}{c}24.389 * * * \\
(7.551)\end{array}$ & $\begin{array}{c}7.999 * * * \\
(3.021)\end{array}$ & $\begin{array}{l}6.277 * * \\
(2.843)\end{array}$ & $\begin{array}{c}1.722^{* * *} \\
(0.523)\end{array}$ \\
\hline $\begin{array}{l}\text { Observations } \\
\text { First-Stage F }\end{array}$ & 11358 & 11358 & $\begin{array}{l}11358 \\
23.29\end{array}$ & $\begin{array}{l}11358 \\
23.29\end{array}$ & $\begin{array}{l}11358 \\
23.29\end{array}$ \\
\hline
\end{tabular}

